\title{
Sea-level changes in Iceland and the influence of the North Atlantic Oscillation during the last half millennium
}

\author{
Margot H. Saher ${ }^{\text {a, }}{ }^{*}$, W. Roland Gehrels ${ }^{b}$, Natasha L.M. Barlow ${ }^{c}$, Antony J. Long ${ }^{c}$, \\ Ivan D. Haigh ${ }^{\mathrm{d}}$, Maarten Blaauw ${ }^{\mathrm{e}}$ \\ a School of Ocean Sciences, Bangor University, Menai Bridge LL59 5AB, UK \\ ${ }^{\mathrm{b}}$ Environment Department, University of York, Heslington, York YO10 5DD, UK \\ c Department of Geography, Durham University, South Road, Durham DH1 3LE, UK \\ d Ocean and Earth Science, National Oceanography Centre, University of Southampton, European Way Southampton SO14 3ZH, UK \\ e School of Geography, Archaeology and Palaeoecology, Queen's University Belfast, Elmwood Avenue, Belfast BT7 1NN, UK
}

\section{A R T I C L E I N F O}

\section{Article history:}

Received 19 December 2013

Received in revised form 29 August 2014

Accepted 6 November 2014

Available online 26 November 2014

\section{Keywords:}

Diatoms

Ocean dynamics

Iceland

Little Ice Age

Sea-level rise

NAO

\begin{abstract}
A B S T R A C T
We present a new, diatom-based sea-level reconstruction for Iceland spanning the last $~ 500$ years, and investigate the possible mechanisms driving the sea-level changes. A sea-level reconstruction from near the Icelandic low pressure system is important as it can improve understanding of ocean-atmosphere forcing on North Atlantic sea-level variability over multi-decadal to centennial timescales. Our reconstruction is from Viðarhólmi salt marsh in Snæfellsnes in western Iceland, a site from where we previously obtained a 2000-yr record based upon less precise sea-level indicators (salt-marsh foraminifera). The 20th century part of our record is corroborated by tide-gauge data from Reykjavik. Overall, the new reconstruction shows ca $0.6 \mathrm{~m}$ rise of relative sea level during the last four centuries, of which ca $0.2 \mathrm{~m}$ occurred during the 20th century. Low-amplitude and high-frequency sea-level variability is superimposed on the pre-industrial long-term rising trend of $0.65 \mathrm{~m}$ per 1000 years. Most of the relative sea-level rise occurred in three distinct periods: AD 1620-1650, AD 1780-1850 and AD 1950-2000, with maximum rates of $\sim 3 \pm 2 \mathrm{~mm} / \mathrm{yr}$ during the latter two of these periods. Maximum rates were achieved at the end of large shifts (from negative to positive) of the winter North Atlantic Oscillation (NAO) Index as reconstructed from proxy data. Instrumental data demonstrate that a strong and sustained positive NAO (a deep Icelandic Low) generates setup on the west coast of Iceland resulting in rising sea levels. There is no strong evidence that the periods of rapid sea-level rise were caused by ocean mass changes, glacial isostatic adjustment or regional steric change. We suggest that wind forcing plays an important role in causing regional-scale coastal sea-level variability in the North Atlantic, not only on (multi-)annual timescales, but also on multi-decadal to centennial timescales.
\end{abstract}

๑) 2014 Elsevier Ltd. All rights reserved.

\section{Introduction}

Determining the nature and causes of sea-level variability in the pre-industrial era provides a long-term context for comparing recent sea-level trends and for developing future projections (e.g. Van de Plassche, 2000; Gehrels et al., 2004; Milne et al., 2009; Kemp et al., 2011; Barlow et al., 2012). Driving mechanisms of sea-level changes include mass changes in land-based ice, and other processes such as steric expansion and contraction, and

\footnotetext{
* Corresponding author. Tel.: +44 1248 383819; fax: +44 1248716367

E-mail address: m.saher@bangor.ac.uk (M.H. Saher).
}

dynamic oceanographic processes including variations in wind stress and atmospheric pressure (Gehrels and Woodworth, 2013).

Unravelling the relative importance of these processes on multidecadal to centennial timescales requires the development of precise proxy-based sea-level reconstructions that extend before the start of instrumental observations, with good age (decadal) and height (sub-decimetre) control. In the North Atlantic, the most precise reconstructions are developed along low-energy coastlines with small tidal ranges where organic-rich salt marshes provide environments that are suitable for developing continuous sea-level records over the last few millennia (e.g. Gehrels et al., 2005; Kemp et al., 2011). 
Identifying the drivers of regional sea-level change demands multiple observations from different parts of any particular ocean basin, which by necessity will be from a variety of depositional and tidal range environments (Long et al., 2014). A variety of microfossil types that include foraminifera, testate amoebae and diatoms are typically used, on their own or occasionally in combination, to constrain palaeomarsh surface elevations and past sea-level changes (e.g. Gehrels et al., 2001; Kemp et al., 2009; Charman et al., 2010; Barlow et al., 2013).

In this paper we develop a new relative sea-level (RSL) reconstruction from a meso-tidal salt marsh in western Iceland, an area particularly susceptible to wind-driven sea-level variability due to its location in the pathway of low pressure systems. In a previous paper Gehrels et al. (2006) reconstructed a 2000-yr record from this site using foraminifera (Fig. 1), and identified a single acceleration in sea level that was dated to the beginning of the nineteenth century. However, the record was heavily dominated by the upper marsh species Jadammina macrescens with occasional Paratrochammina (Lepidoparatrochammina) haynesi. This low species diversity provided limited constraints on the elevation of the formation of the past marsh surface, making it impossible to identify any fluctuations in relative sea-level change beyond the 19th century inflection. Here we revisit the study site, Viðarhólmi salt marsh, and focus in on the last five centuries. We exploit the greater sensitivity to elevation (and hence sea level) of diatoms to produce a 500-yr sea-level reconstruction of high vertical precision. We also apply new chronological analyses to the upper part of the stratigraphic section previously studied to generate an improved age model using new tephra and AMS ${ }^{14} \mathrm{C}$ dates, in combination with previous AMS ${ }^{14} \mathrm{C},{ }^{137} \mathrm{Cs}$ and chemostratigraphical analyses. The resulting reconstruction identifies three distinct periods of rapid sea-level rise during the last $\sim 500$ years.

To assess the potential drivers behind these changes we compare the new record to proxy and instrumental reconstructions of the North Atlantic Oscillation (NAO) Index over the same interval.
The NAO exerts a strong influence over regional wind patterns, precipitation and temperature, mainly in the winter (e.g. Hurrell et al., 2003). The influence of (winter) NAO (wNAO) on Atlantic sea level during the instrumental era is well established (Andersson, 2002; Woolf et al., 2003; Tsimplis et al., 2005, 2006; Kolker and Hameed, 2007; Miller and Douglas, 2007; Woodworth et al., 2007; Haigh et al., 2010), but its significance in controlling dynamic sea-level variability over longer time intervals has not previously been explored. In this paper we present proxy evidence of at least two pre-industrial oscillations in sea level that broadly correlate to changes in reconstructed wNAO in the North Atlantic Ocean, highlighting the influence of ocean-atmosphere forcing on regional-scale sea-level variability during past centuries.

\section{Study area}

Viðarhólmi salt marsh $\left(64.77^{\circ} \mathrm{N}, 22.42^{\circ} \mathrm{W}\right)$ is located on the west coast of Iceland (Fig. 1 ) in an area that has been seismically stable during the late Holocene (Angelier et al., 2004). Árnadóttir et al. (2009) estimate modest rates of uplift due to GIA $(\sim 1 \mathrm{~mm} / \mathrm{yr})$ in the period AD 1993-2004 based on GPS observations, but Gehrels et al. (2006) documented $1.3 \mathrm{~m}$ of relative sea-level rise during the last 2000 years, indicating that on millennial time scales this coastal area is subsiding. The marsh is underlain by Tertiary basalt (Ward, 1971), and protected by a barrier spit to the south and by an outcropping Holocene lava flow to the east. Several tidal channels dissect the salt marsh. Our fossil sediment section is taken from the cleaned face of one of these channels where a $2 \mathrm{~m}$ high peat section is exposed (Figs. 1 and 2). This is the same section where monoliths for the Gehrels et al. (2006) study had been taken in 2001 and 2003. Today the salt marsh is largely undisturbed by human influence but is occasionally grazed by sheep. Dominant plants on the marsh are Carex lyngbyei, Agrostis stolonifera, Festuca rubra and Puccinellia maritima (Ingólfsson, 1998). Mean tidal range at Viðarhólmi is $2.1 \mathrm{~m}$, mean sea level (MSL) is $0.12 \mathrm{~m}$ above the Iceland geodetic
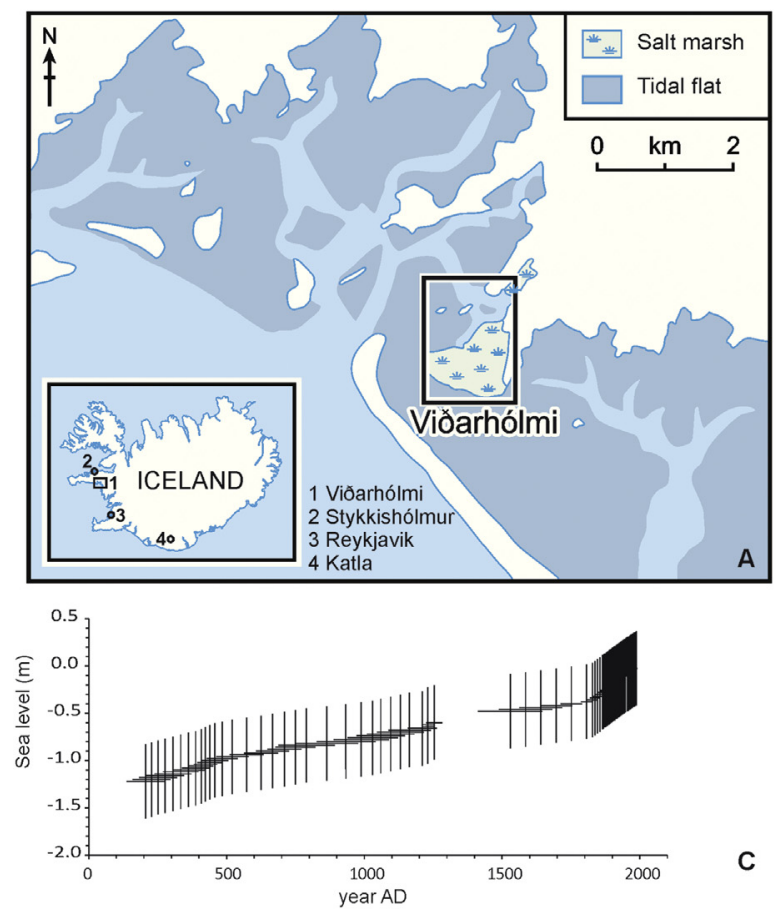

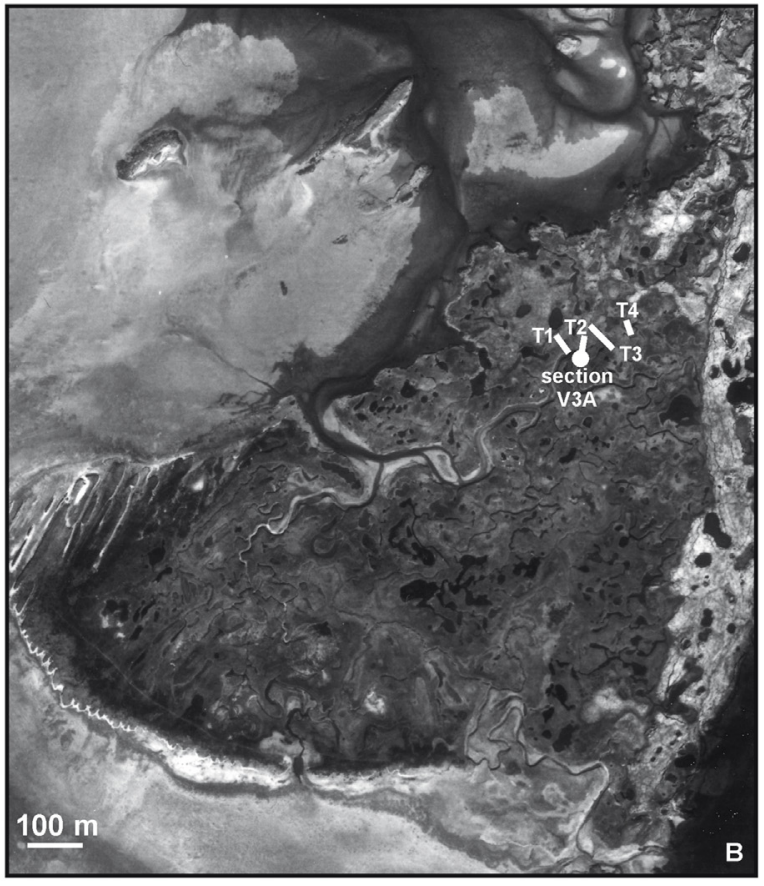

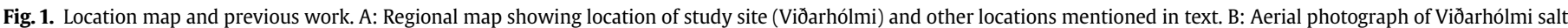

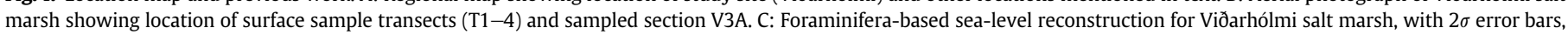
spanning the last 2000 years from Gehrels et al. (2006). 


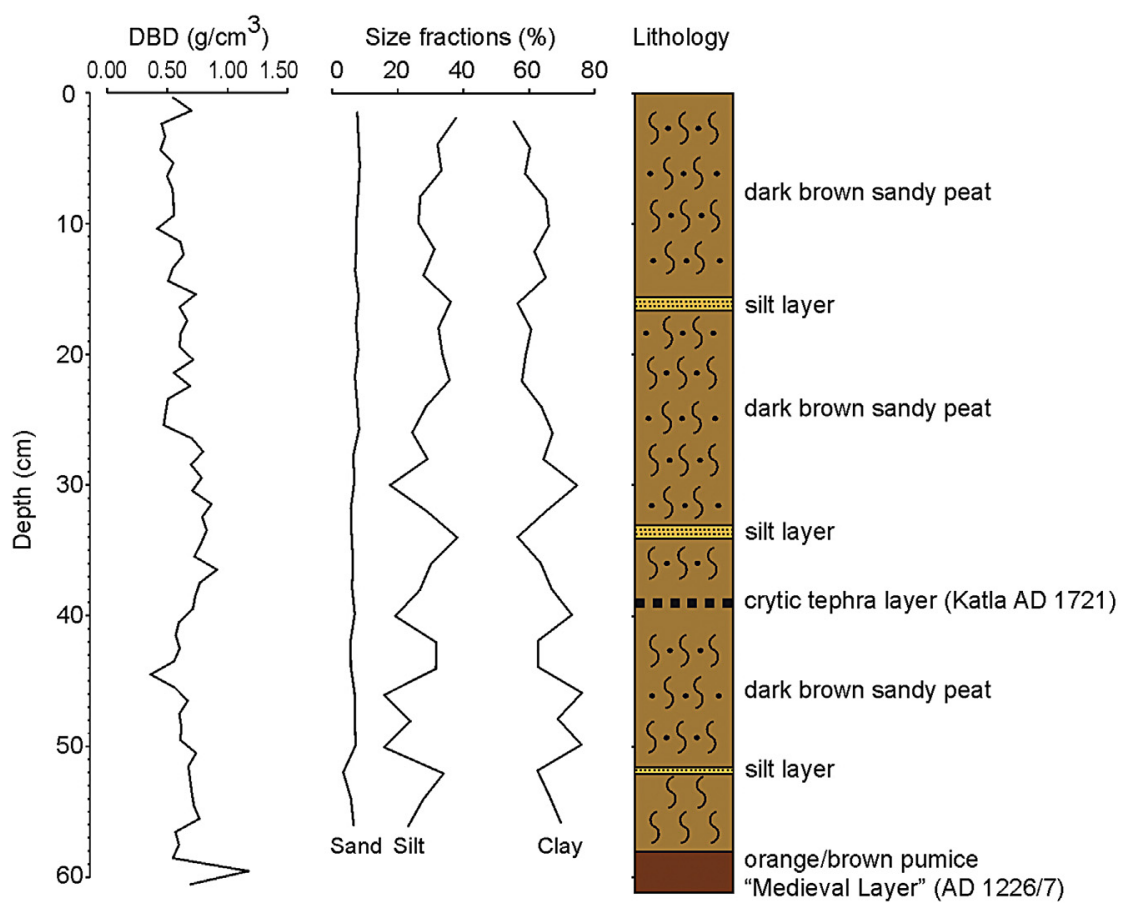

Fig. 2. Stratigraphy and sedimentological data of section V3A, showing dry bulk density (DBD), grain-size fractions and lithology (including dated tephras).

datum and the highest astronomical tides reach $\sim 2.1 \mathrm{~m}$ above MSL (Gehrels et al., 2006).

Wind patterns in western Iceland are controlled by the position and strength of the Icelandic low pressure system which generally results in dominant wind directions from the east, with only rare westerlies (Einarsson, 1984). During positive phases of the NAO the Icelandic Low tends to deepen and is located further north than during negative phases (Serreze et al., 1997). In the 1930s, for example, the average position of the Icelandic low was at $61^{\circ} \mathrm{N}$, while the shift to a negative NAO mode from the 1940s to the 1970s was associated with a southward movement of this low to around $59^{\circ} \mathrm{N}$ (Angell and Korshover, 1974). In addition, extra-tropical cyclones tend to track along a more northerly path and are more frequent during a positive NAO mode (Carleton, 1988).

\section{Methods}

\subsection{Field and laboratory methods}

In September 2009 we cleaned and re-sampled the upper $60 \mathrm{~cm}$ of section 3A of Gehrels et al. (2006) using monolith tins driven into the cleaned sediment surface. The lithostratigraphy of the marsh is detailed in Gehrels et al. (2006) and mainly comprises sandy peat (Fig. 2). Sand- and silt-sized material in the section is of volcanic origin and includes tephra. Three distinct horizons of silt are visible in the sequence at $54 \mathrm{~cm}, 34 \mathrm{~cm}$ and $14 \mathrm{~cm}$. Section $3 \mathrm{~A}$ contains an orange-brown pumice at 58-60 cm, dated to 1226/7 (Gehrels et al., 2006), which we used as the base of the re-sampled section.

We sampled modern diatoms from four transects across a height range of $0.74 \mathrm{~m}$ (35\% of the tidal range) from just above the Highest Astronomical Tide (HAT) to the coring site in the lower part of the mid marsh at an elevation between Mean High Water Springs (MHWS) and Mean High Water (MHW) (Fig. 1, Supplementary information Table 1). Surface samples were collected with a cylindrical turf cutter. The top $1 \mathrm{~cm}$ was sub-sampled in the laboratory for diatom analysis. Heights of sample sites were surveyed relative to geodetic and tidal datums with a Total Station. Samples for diatom analysis were prepared using the techniques detailed in Palmer and Abbott (1986). Diatoms were identified using Foged (1974), Hartley et al. (1996), Hemphill-Haley (1993), van der Werff and Huls (1957-1974) and classified by the halobian classification system (Hustedt, 1953; Hemphill-Haley, 1993).

\subsection{Transfer functions}

We applied a transfer function (Birks et al., 1990) based on present-day microfossil assemblages to obtain estimates of palaeomarsh surface elevation from the down-core fossil assemblages. Using detrended canonical correspondence analysis (DCCA) in CANOCO version 4.5 (Ter Braak and Smilauer, 2002) we calculated the length of the environmental gradient of the modern diatom dataset at 2.2 standard deviation units. We therefore followed the general rule of thumb that, because the DCCA gradient length is greater than 2 standard deviation units, sufficient species in the training set have their optima located along the environmental gradient and are collectively responding unimodally to elevation across the marsh surface (Ter Braak and Prentice, 1988). We developed a unimodal weighted averaging partial least squared (WA-PLS) model (Ter Braak and Juggins, 1993) using the software $C^{2}$ (Juggins, 2003). We selected a WA-PLS model with two components $\left(r^{2}=0.75\right.$, Root Mean Squared Error of Prediction $($ RMSEP $)=0.09)$ as this provided a $>10 \%$ improvement in $r^{2}$ boot and RMSEP compared to a one component model. Adding further components did not significantly improve model performance. The observed versus predicted marsh surface elevations are shown in Fig. 3. The WA-PLS diatom model predicts the elevation of the core top to within $1 \mathrm{~cm}$.

We evaluated the similarity between the modern and fossil assemblages, and therefore the robustness of our reconstructions, using the modern analogue technique (MAT) (Overpeck et al., 1985; Jackson and Williams, 2004). We considered fossil samples with a minimum dissimilarity coefficient (minDC) smaller than the 5 th 

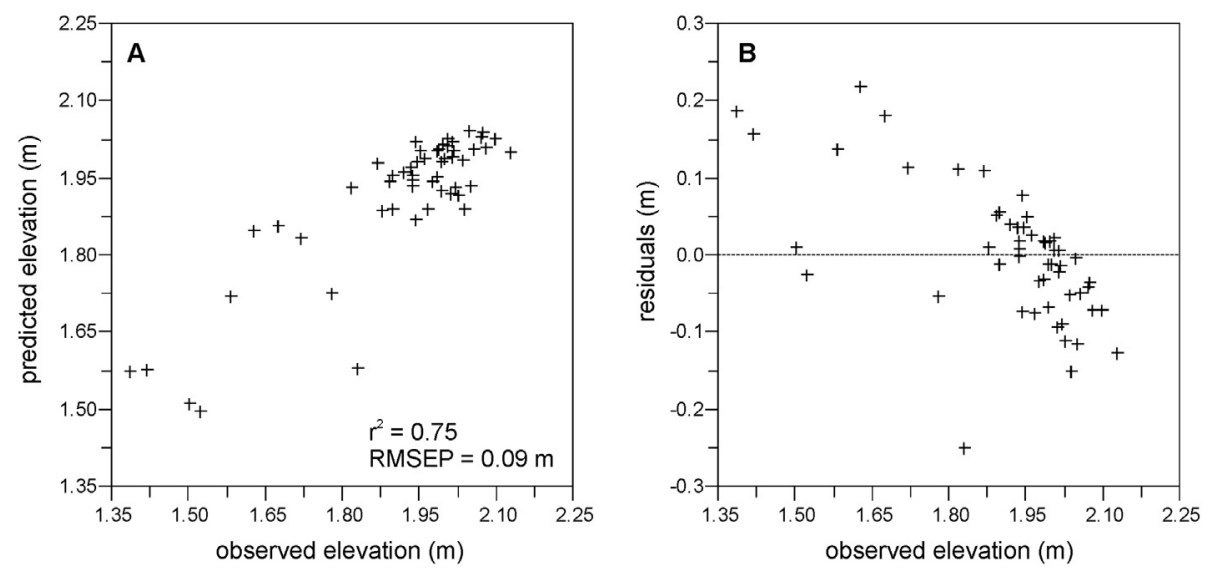

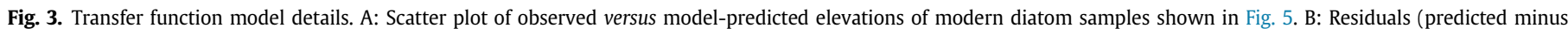
observed sample elevations). RMSEP - root mean squared error of prediction.

percentile as having a good analogue, those with a minDC between the 5th and the 20th percentile as having a close analogue, and those with a minDC of more than the 20th percentiles as having a poor modern analogue (Simpson, 2007; Watcham et al., 2013). We removed all samples with a poor modern analogue from our resulting RSL reconstructions.

\subsection{Chronology}

We added nine high-precision AMS ${ }^{14} \mathrm{C}$ dates (Bronk Ramsey et al., 2004), four bomb-spike AMS ${ }^{14} \mathrm{C}$ dates, and a tephra marker to the existing chronological data of Gehrels et al. (2006) (Table 1). The chronology of the 2006 record was based on conventional AMS ${ }^{14} \mathrm{C},{ }^{137} \mathrm{Cs}, \mathrm{Pb} / \mathrm{Li},{ }^{206} \mathrm{~Pb} /{ }^{207} \mathrm{~Pb}$ and magnetic declination measurements. The new high-precision AMS ${ }^{14} \mathrm{C}$ dates were obtained from fragile, horizontally embedded, detrital plant remains, and the exoskeletons of a (non-burrowing) weevil (Otiorhynchus sp.). These analyses were conducted at the NERC Radiocarbon Facility within the Scottish Universities Environmental Research Centre, East Kilbride, Scotland.

Within the core we detected tephra that erupted in AD 1721 from the Katla volcano located ca 200 km southeast of Viðarhólmi.

Table 1

Age-depth data used to reconstruct relative sea-level changes in western Iceland during the last 500 years. Sources: 1 - this study; 2 - Gehrels et al. (2006).

\begin{tabular}{|c|c|c|c|c|c|c|c|c|c|c|c|c|}
\hline $\begin{array}{l}\text { Depth of } \\
\text { date }(\mathrm{cm})\end{array}$ & $\begin{array}{l}\text { Depth of } \\
\text { modelled } \\
\text { age }(\mathrm{cm})\end{array}$ & Source & $\begin{array}{l}\text { Dating } \\
\text { method/ } \\
\text { marker }\end{array}$ & Lab. Code & Dry weight (mg) & Material & $\begin{array}{l}{ }^{14} \mathrm{C} \text { enrichment } \\
(\% \text { modern } \pm 1 \mathrm{~s})\end{array}$ & $\begin{array}{l}{ }^{14} \mathrm{C} \text { year } \\
\mathrm{BP} \pm 1 \mathrm{~s}\end{array}$ & Age & $\begin{array}{l}\text { Modelled } \\
\text { age AD }\end{array}$ & $\begin{array}{l}\text { Min. } \\
\text { age AD }\end{array}$ & $\begin{array}{l}\text { Max. } \\
\text { age AD }\end{array}$ \\
\hline 0.0 & 0.0 & 2 & Surface & & & & & & $2001 \pm 1$ & 2001.6 & 1999.9 & 2003.4 \\
\hline 0.5 & 0.5 & 2 & ${ }^{137} \mathrm{Cs}$ & & & & & & $2000 \pm 1$ & 1999.7 & 1998 & 2001.3 \\
\hline 1.5 & 1.5 & 2 & ${ }^{137} \mathrm{Cs}$ & & & & & & $1995 \pm 2$ & 1995.4 & 1992.8 & 1998 \\
\hline 2.5 & 2.5 & 2 & ${ }^{137} \mathrm{Cs}$ & & & & & & $1990 \pm 3$ & 1991.2 & 1987.8 & 1994.5 \\
\hline 3.5 & 3.5 & 2 & ${ }^{137} \mathrm{Cs}$ & & & & & & $1986 \pm 4$ & 1987.6 & 1984 & 1991.3 \\
\hline 4.5 & 4.5 & 2 & ${ }^{137} \mathrm{Cs}$ & & & & & & $1982 \pm 4$ & 1984.2 & 1980.6 & 1988 \\
\hline 5.5 & 5.5 & 2 & ${ }^{137} \mathrm{Cs}$ & & & & & & $1978 \pm 5$ & 1981.2 & 1977.6 & 1984.6 \\
\hline 6.5 & 6.5 & 2 & ${ }^{137} \mathrm{Cs}$ & & & & & & $1974 \pm 6$ & 1978.4 & 1975.4 & 1981.5 \\
\hline 7.5 & 7.5 & 2 & ${ }^{137} \mathrm{Cs}$ & & & & & & $1970 \pm 6$ & 1975.9 & 1973.2 & 1978.2 \\
\hline 8.2 & 8.2 & 1 & ${ }^{14} \mathrm{C}$ bomb & SUERC-32116 & 1.2 & $\begin{array}{l}\text { Weevil } \\
\text { (Otiorhynchus sp.) } \\
\text { exoskeleton }\end{array}$ & $140.08 \pm 0.87$ & & & 1974.6 & 1971.8 & 1976.9 \\
\hline 8.5 & 8.5 & 2 & ${ }^{137} \mathrm{Cs}$ & & & & & & $1965 \pm 7$ & 1973 & 1970.6 & 1974.7 \\
\hline 9.0 & 9.0 & 2 & ${ }^{206} \mathrm{~Pb}^{/ 207} \mathrm{~Pb}, \mathrm{~Pb} / \mathrm{Li}$ & & & & & & $1960 \pm 5$ & 1971.3 & 1968.2 & 1973.8 \\
\hline 9.5 & 9.5 & 2 & ${ }^{137} \mathrm{Cs}$ & & & & & & $1961 \pm 8$ & 1969.8 & 1967.1 & 1972.2 \\
\hline 10.5 & 10.5 & 2 & ${ }^{137} \mathrm{Cs}$ & & & & & & $1957 \pm 9$ & 1966.9 & 1964.5 & 1969.5 \\
\hline 11.1 & 11.0 & 1 & ${ }^{14} \mathrm{C}$ bomb & SUERC-32119 & 1.7 & Plant detritus & $172.09 \pm 0.91$ & & & 1965.5 & 1963.4 & 1968.2 \\
\hline 11.5 & 11.5 & 2 & ${ }^{137} \mathrm{Cs}$ & & & & & & $1953 \pm 9$ & 1962.7 & 1960.4 & 1965.3 \\
\hline 15.9 & 16.0 & 1 & ${ }^{14} \mathrm{C}$ bomb & SUERC-32002 & 7.7 & Plant detritus & $127.04 \pm 0.25$ & & & 1927 & 1911.9 & 1940.1 \\
\hline 16.0 & 16.0 & 2 & ${ }^{206} \mathrm{~Pb} /{ }^{207} \mathrm{~Pb}$ & & & & & & $1925 \pm 10$ & 1927 & 1911.9 & 1940.1 \\
\hline 20.3 & 20.0 & 1 & ${ }^{14} \mathrm{C}$ bomb & SUERC-32502 & 4.1 & Plant detritus & $103.22 \pm 0.21$ & & & 1893.8 & 1871.3 & 1912.8 \\
\hline 24.1 & 24.0 & 1 & ${ }^{14} \mathrm{C}$ & SUERC-32003 & 3.2 & Plant detritus & $99.66 \pm 0.19$ & $27 \pm 16$ & & 1858.6 & 1832.3 & 1885.2 \\
\hline 34.5 & 34.5 & 1 & ${ }^{14} \mathrm{C}$ & SUERC-32005 & 6.4 & Plant detritus & $97.55 \pm 0.19$ & $199 \pm 16$ & & 1770.5 & 1750.3 & 1790 \\
\hline 36.0 & 36.0 & 2 & ${ }^{14} \mathrm{C}$ & AAR-8031 & 12.5 & Plant detritus & $\mathrm{n} / \mathrm{a}$ & $105 \pm 47$ & & 1757.1 & 1739.4 & 1774.8 \\
\hline 38.2 & 38.0 & 1 & ${ }^{14} \mathrm{C}$ & SUERC-32011 & 5.3 & Plant detritus & $97.79 \pm 0.19$ & $180 \pm 16$ & & 1738.3 & 1725.4 & 1753.1 \\
\hline 39.0 & 39.0 & 1 & Katla 1721 ash & & & & & & $1721 \pm 1$ & 1728.1 & 1719.4 & 1738 \\
\hline 39.0 & 39.0 & 2 & ${ }^{14} \mathrm{C}$ & AAR-8032 & 6.2 & Plant detritus & $\mathrm{n} / \mathrm{a}$ & $168 \pm 43$ & & 1728.1 & 1719.4 & 1738 \\
\hline 39.0 & 39.0 & 2 & Declination & & & & & & $1820 \pm 20$ & 1728.1 & 1719.4 & 1738 \\
\hline 41.0 & 41.0 & 1 & ${ }^{14} \mathrm{C}$ & SUERC-32012 & 7.1 & Plant detritus & $97.59 \pm 0.20$ & $196 \pm 16$ & & 1690.6 & 1674 & 1706.5 \\
\hline 42.2 & 42.5 & 1 & ${ }^{14} \mathrm{C}$ & SUERC-39555 & 3.1 & Plant detritus & $97.84 \pm 0.43$ & $175 \pm 35$ & & 1665.5 & 1646.7 & 1686.9 \\
\hline 44.9 & 45.0 & 1 & ${ }^{14} \mathrm{C}$ & SUERC-40502 & 2 & Plant detritus & $98.16 \pm 0.48$ & $149 \pm 39$ & & 1630.1 & 1587.9 & 1661.9 \\
\hline 47.2 & 47.5 & 1 & ${ }^{14} \mathrm{C}$ & SUERC-39565 & 4.1 & Weevil & $96.37 \pm 0.42$ & $297 \pm 35$ & & 1585.8 & 1542.2 & 1628.3 \\
\hline 51.0 & 51.0 & 2 & ${ }^{14} \mathrm{C}$ & AAR-8033 & 8.4 & Plant detritus & $\mathrm{n} / \mathrm{a}$ & $314 \pm 36$ & & 1523.1 & 1483.1 & 1567.3 \\
\hline 52.3 & 52.5 & 1 & ${ }^{14} \mathrm{C}$ & SUERC-32503 & 4.2 & Plant detritus & $96.16 \pm 0.20$ & $315 \pm 17$ & & 1495 & 1459.8 & 1534.6 \\
\hline 54.1 & 54.0 & 1 & ${ }^{14} \mathrm{C}$ & SUERC-39556 & 2.8 & Plant detritus & $95.06 \pm 0.41$ & $407 \pm 35$ & & 1460.9 & 1425.7 & 1501.6 \\
\hline
\end{tabular}


This is an exceptional find because other historic Katla tephras (such as AD 1755) were transported by winds in a northeasterly direction and did not reach our field site (Haflidason et al., 2000). The original Gehrels et al. (2006) age model suggested that the Katla AD 1721 tephra (Larsen, 2000) could be located in the sampled sequence between 34 and $48 \mathrm{~cm}$. We therefore targeted this depth range at $1 \mathrm{~cm}$ intervals, sieving samples and examining the 25-63 $\mu \mathrm{m}$ fraction under a light microscope. About 60 tephra shards were picked from each sample, and prepared for electron probe analysis at the School of Geosciences, University of Edinburgh. We selected 154 grains on the basis of successful preparation and pristineness of the material, and analysed their chemical composition on a Cameca SX100 electron microprobe, with rhyolitic (Lipari) and basaltic (BCR2g) standards used for calibration (see Hayward, 2012). We identified 39 grains with Katla geochemistry (Einarsson et al., 1980; Óladóttir et al., 2008) (Supplementary Information Table 2), of which nine had the characteristic $\mathrm{K}_{2} \mathrm{O}$ / $\mathrm{P}_{2} \mathrm{O}_{5}$ signature of historic Katla eruptions (Óladóttir et al., 2008). A maximum of five historic Katla grains per sample were found at $39 \mathrm{~cm}$; all other samples contained one shard at most. On this basis we assigned a date of AD 1721 to the level at $39 \mathrm{~cm}$, assuming that bioturbation and remobilisation by wind and water subsequently re-distributed some shards over a wider depth range (e.g. Davies et al., 2007).

We developed our age-depth model (Fig. 3) using the Bacon package in $\mathrm{R}$ (Blaauw and Christen, 2011). Bacon requires as input a prior mean accumulation rate which we calculated using the depth of the AD 1226-7 pumice tephra at $58 \mathrm{~cm}$ (Haflidason et al., 1992; Sigurgeirsson, 1992; Gehrels et al., 2006). In the 2001, 2003 and 2009 monoliths the pumice tephra was found at $58 \mathrm{~cm}$, suggesting negligible sedimentation between sample collection dates. Although this does not allow us to reconstruct sea-level changes during the past decade, it does enable all analyses to be easily combined into one chronology. The stratigraphy and our age-depth model do not show evidence of other significant hiatuses in the record.

\subsection{Sea-level reconstructions}

We translated the palaeo-marsh elevations calculated by the transfer functions into relative sea level (RSL) using the equation (e.g. Gehrels, 1999):

$$
\begin{aligned}
\operatorname{RSL}(\mathrm{m})= & \text { sample height }(\mathrm{m} \mathrm{MSL}) \\
& - \text { palaeomarsh elevation }(\mathrm{m} \mathrm{MSL})
\end{aligned}
$$

Results are presented in Table 2. The sample-specific bootstrapped RMSEP gives the vertical uncertainty (approximate to $1 \sigma$ ) for each fossil sample, although in the figures we multiplied the errors by 1.96 to $2 \sigma$. All sample ages and errors are based on modelled ages; those from dated levels have reduced uncertainties compared to those from intermediate (undated) levels. On the basis of four ${ }^{14} \mathrm{C}$-dated sea-level index points that directly overlie bedrock, Gehrels et al. (2006) concluded that the section is free of any significant compaction. This is in agreement with the compaction studies of Brain et al. (2012) who found that thin, lithologically homogeneous stratigraphies, like the one described here, are not significantly affected by compaction.

To calculate error envelopes for our sea-level reconstruction we resampled the RSL data points in $\mathrm{R}$ using their individual age and vertical error estimates. For each of 1000 iterations, we sampled random values from the means and ( 1 standard deviation) errors of the age and RSL estimates (assuming normal distributions) and calculated smooth splines (smoothing parameter 0.8) through the resampled data points. From the resulting family of 1000 smooth
Table 2

Icelandic sea-level data for the last 500 years. I.M. - indicative meaning. MSL mean sea level. Relative sea level (RSL) positions are given relative to present sea

\begin{tabular}{|c|c|c|c|c|c|c|c|}
\hline $\begin{array}{l}\text { Depth below } \\
\text { surface }(\mathrm{cm})\end{array}$ & $\begin{array}{l}\text { Height } \\
\text { (m MSL) }\end{array}$ & Age AD & $\begin{array}{l}\text { Age } \\
\text { error } \\
(+2 \sigma)\end{array}$ & $\begin{array}{l}\text { Age } \\
\text { error } \\
(-2 \sigma)\end{array}$ & $\begin{array}{l}\text { I.M. } \\
\text { (m MSL) }\end{array}$ & $\mathrm{RSL}(\mathrm{m})$ & $\begin{array}{l}\text { RSL } \\
\text { error } \\
(\mathrm{m}, 2 \sigma)\end{array}$ \\
\hline 0.0 & 1.940 & 2002 & 1.8 & 1.7 & 1.952 & -0.012 & 0.181 \\
\hline 1.0 & 1.930 & 1998 & 2.6 & 3.1 & 1.940 & -0.010 & 0.181 \\
\hline 1.5 & 1.925 & 1995 & 2.6 & 2.6 & 1.847 & 0.078 & 0.183 \\
\hline 3.5 & 1.905 & 1988 & 3.7 & 3.6 & 1.887 & 0.018 & 0.178 \\
\hline 4.5 & 1.895 & 1984 & 3.8 & 3.6 & 1.958 & -0.063 & 0.175 \\
\hline 5.0 & 1.890 & 1983 & 4.0 & 3.8 & 1.959 & -0.069 & 0.176 \\
\hline 5.5 & 1.885 & 1981 & 3.4 & 3.6 & 1.888 & -0.003 & 0.177 \\
\hline 7.5 & 1.865 & 1976 & 2.3 & 2.7 & 1.948 & -0.083 & 0.175 \\
\hline 8.0 & 1.860 & 1975 & 2.3 & 2.8 & 1.877 & -0.017 & 0.177 \\
\hline 8.5 & 1.855 & 1973 & 1.7 & 2.4 & 1.933 & -0.078 & 0.176 \\
\hline 9.0 & 1.850 & 1971 & 2.5 & 3.1 & 1.877 & -0.027 & 0.181 \\
\hline 9.5 & 1.845 & 1970 & 2.4 & 2.7 & 1.882 & -0.037 & 0.185 \\
\hline 10.0 & 1.840 & 1968 & 3.1 & 3.1 & 1.903 & -0.063 & 0.177 \\
\hline 10.5 & 1.835 & 1967 & 2.6 & 2.4 & 1.928 & -0.093 & 0.176 \\
\hline 11.0 & 1.830 & 1966 & 2.7 & 2.1 & 1.930 & -0.100 & 0.180 \\
\hline 11.5 & 1.825 & 1963 & 2.6 & 2.3 & 1.955 & -0.130 & 0.183 \\
\hline 12.5 & 1.815 & 1956 & 5.7 & 6.9 & 1.931 & -0.116 & 0.183 \\
\hline 15.0 & 1.790 & 1935 & 12.7 & 14.7 & 1.895 & -0.105 & 0.182 \\
\hline 16.0 & 1.780 & 1927 & 13.1 & 15.1 & 1.879 & -0.099 & 0.182 \\
\hline 17.5 & 1.765 & 1915 & 15.7 & 17.8 & 1.987 & -0.222 & 0.178 \\
\hline 20.0 & 1.740 & 1894 & 19.0 & 22.5 & 1.892 & -0.152 & 0.178 \\
\hline 20.5 & 1.735 & 1890 & 19.3 & 23 & 1.918 & -0.183 & 0.179 \\
\hline 22.5 & 1.715 & 1872 & 23.5 & 25.8 & 1.865 & -0.150 & 0.187 \\
\hline 24.0 & 1.700 & 1859 & 26.6 & 26.3 & 1.850 & -0.150 & 0.191 \\
\hline 25.0 & 1.690 & 1850 & 27.7 & 25.1 & 1.842 & -0.152 & 0.183 \\
\hline 27.0 & 1.670 & 1834 & 26.3 & 22.6 & 1.918 & -0.248 & 0.191 \\
\hline 27.5 & 1.665 & 1830 & 25.9 & 22.1 & 1.933 & -0.268 & 0.189 \\
\hline 30.0 & 1.640 & 1809 & 24.6 & 22.3 & 1.946 & -0.306 & 0.188 \\
\hline 32.5 & 1.615 & 1787 & 22.2 & 21.3 & 2.026 & -0.411 & 0.177 \\
\hline 34.5 & 1.595 & 1771 & 19.5 & 20.2 & 1.983 & -0.388 & 0.174 \\
\hline 35.0 & 1.590 & 1766 & 19.1 & 20.4 & 1.995 & -0.405 & 0.181 \\
\hline 36.0 & 1.580 & 1757 & 17.7 & 17.7 & 1.960 & -0.380 & 0.176 \\
\hline 37.5 & 1.565 & 1743 & 15.0 & 13.6 & 1.964 & -0.399 & 0.185 \\
\hline 38.0 & 1.560 & 1738 & 14.8 & 12.9 & 2.014 & -0.454 & 0.178 \\
\hline 39.0 & 1.550 & 1728 & 9.9 & 8.7 & 1.999 & -0.449 & 0.175 \\
\hline 40.0 & 1.540 & 1710 & 4.8 & 5.6 & 1.898 & -0.358 & 0.177 \\
\hline 41.0 & 1.530 & 1691 & 15.9 & 16.6 & 1.944 & -0.414 & 0.179 \\
\hline 42.5 & 1.515 & 1666 & 21.4 & 18.8 & 1.872 & -0.357 & 0.177 \\
\hline 45.0 & 1.490 & 1630 & 31.8 & 42.2 & 1.997 & -0.507 & 0.177 \\
\hline 48.5 & 1.455 & 1567 & 43.9 & 42.8 & 2.025 & -0.570 & 0.176 \\
\hline
\end{tabular}
level (i.e. $0 \mathrm{~m}$ ).

splines, we calculated $68 \%$ confidence ranges every 5 th year between AD 1500 and 2000. We determined the corresponding rises based on the derivatives of the above smooth splines.

\section{Results}

\subsection{Modern diatoms}

The modern diatom flora of Viðarhólmi salt marsh is diverse, but the 28 taxa with an abundance of $>5 \%$ of the total diatom valves counted (TDV) exhibit a strong vertical zonation across the marsh (Fig. 5). Assemblages are dominated by the genus Navicula, with as most abundant species Navicula ignota, Navicula cincta type, and Navicula salinarum. Other abundant species are Luticola mutica and Nitzschia filiformis.

\subsection{Fossil diatoms}

Fossil diatoms (Fig. 6) in the lower part of the core $(45-55 \mathrm{~cm})$ are characterised by relatively high percentages (up to $40 \%$ TDV) of freshwater species such as Pinnularia borealis. From $\sim 45 \mathrm{~cm}$ upward, the fresh-to brackish-water taxon Navicula cincta type dominates, with a maximum abundance of $71 \%$ TDV at $27 \mathrm{~cm}$. In the 


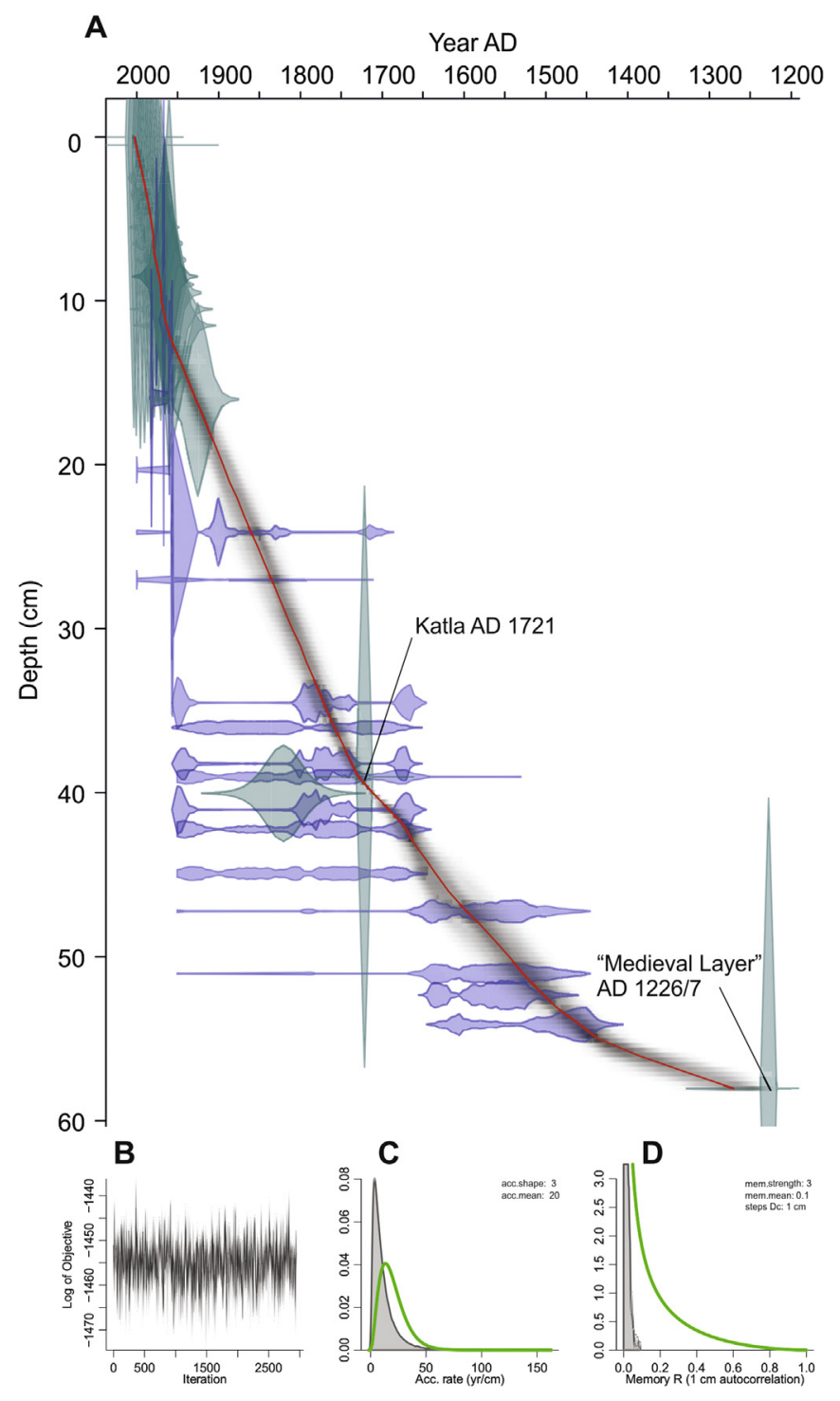

Fig. 4. Age model and output files computed by the software package Bacon (Blaauw and Christen, 2011) for section V3A. A: Age-depth model based on ${ }^{14} \mathrm{C}$ (purple) and other (turquoise) dates. The red curve shows the weighted mean ages of all depths, whereas greyscales show uncertainties (where darker grey indicates more certain sections). B: Stable Markov Chain Monte Carlo run. C: Prior (green curve; gamma distribution with mean 20, shape 3 ) and posterior (grey histogram) distributions for the accumulation rate $(\mathrm{yr} / \mathrm{cm})$. D: Prior (green curve; beta distribution with strength 3 and mean 0.1 ) and posterior (grey histogram) for the memory. Section sizes were set at $5 \mathrm{~mm}$. (For interpretation of the references to colour in this figure legend, the reader is referred to the web version of this article.)

upper $10 \mathrm{~cm}$, Luticola mutica increases in abundance (max. 34\% TDV).

\subsection{Age-depth model}

The age model shows a gradual increase in sedimentation rate from $\sim 0.2 \mathrm{~mm} / \mathrm{yr}$ at the base of the sequence to $3 \mathrm{~mm} / \mathrm{yr}$ near the top (Fig. 4). The sample-specific age uncertainties vary through the section: 95\% uncertainty intervals are 40 years between AD 1570-1650, 20-30 years between AD 1775-1895 and 10-20 years in the periods AD 1650-1775 and AD 1895-1950. Age uncertainties are smallest ( $<10$ years) from AD 1950 onwards. Age uncertainties of our sea-level reconstruction are smaller than those of the individual data points (Fig. 3) due to the Bayesian nature of the calculation. The Bayesian algorithms prohibit age-models with reversals, so that ages that are highly anomalous do not feature strongly in the final age model.

\subsection{Quantitative relative sea-level reconstructions}

We combine the reconstructed marsh surface elevations (Fig. 6) with the age-depth model (Fig. 4) to produce a new record of past RSL change (Fig. 7A). Fig. 7B shows the amended sea-level reconstruction for the past 2000 years, including the older data points of Gehrels et al. (2006). The diatom-based transfer function predicts a palaeomarsh surface elevation for the new samples with close/ good modern analogues of $1.84-2.03 \mathrm{~m}$. This falls within the range of the palaeomarsh surface elevations independently estimated by the foraminifera results in Gehrels et al. (2006). The elevation estimates are primarily controlled by species Navicula ignota, Fragilariforma virescens and Opephora marina. Overall, the reconstruction shows a RSL rise of $\sim 0.6 \mathrm{~m}$ in the last 500 years. Most of the sea-level rise appears to have occurred in three steps, with rapid rise in the 17 th century, the late 18 th to early 19 th century and the 20th century.

\section{Discussion}

\subsection{Comparison with other records}

The diatom-based transfer function produces a robust reconstruction that lies within the error bars of, and thus is corroborated by, the original foraminifera-based reconstruction from this site (Gehrels et al., 2006; Fig. 1C). The high species diversity and species turnover of the diatoms, similar to those found by Patterson et al. (2000) in British Columbia, Canada, reveal several decadal-scale fluctuations in sea level not resolved in the original foraminiferabased reconstruction. Despite samples with poor modern analogues, especially towards the base and in the uppermost samples, we can resolve several sea-level fluctuations.

The pronounced RSL inflection at $\sim \mathrm{AD} 1820$ in the foraminiferabased reconstruction for Viðarhólmi salt marsh (Gehrels et al., 2006) was largely due to an abrupt change in the original age-depth model. Our new age model is smoother and as a result the rapid acceleration is removed. The latter part of the record shows a good fit with the Reykjavik tide-gauge record (Fig. 7A).

The overall rise in RSL identified in our new reconstruction (Fig. 7A) of $0.6 \mathrm{~m}$ during the last $\sim 500$ years cannot be directly compared with global sea-level reconstructions, such as that of Jevrejeva et al. (2006), as the latter is corrected for glacial isostatic adjustment (GIA). We do not correct our record for GIA, as the best available data based on Global Positioning System (GPS) data amounts to $\sim 1 \mathrm{~mm} / \mathrm{yr}$ uplift (Árnadóttir et al., 2009), which is not compatible with the millennial-scale relative sea-level rise documented in the Viðarhólmi sediments (Gehrels et al., 2006). We therefore instead focus on fluctuations in the sea-level record which may provide clues for driving mechanisms.

Interestingly, the proxy RSL reconstructions from the eastern USA (Kemp et al., 2011, 2013), Nova Scotia (Gehrels et al., 2005) and north-west Scotland (Barlow et al., 2014) show little variability during the past millennium before a late 19th to early 20th century inflection. These differences between the Icelandic and other North Atlantic records suggest that regional/local influences play a significant role in driving sea-level variability.

\subsection{West Icelandic sea level and NAO}

The multi-decadal variability observed in our new Iceland record is reminiscent of the fluctuations observed in the North 


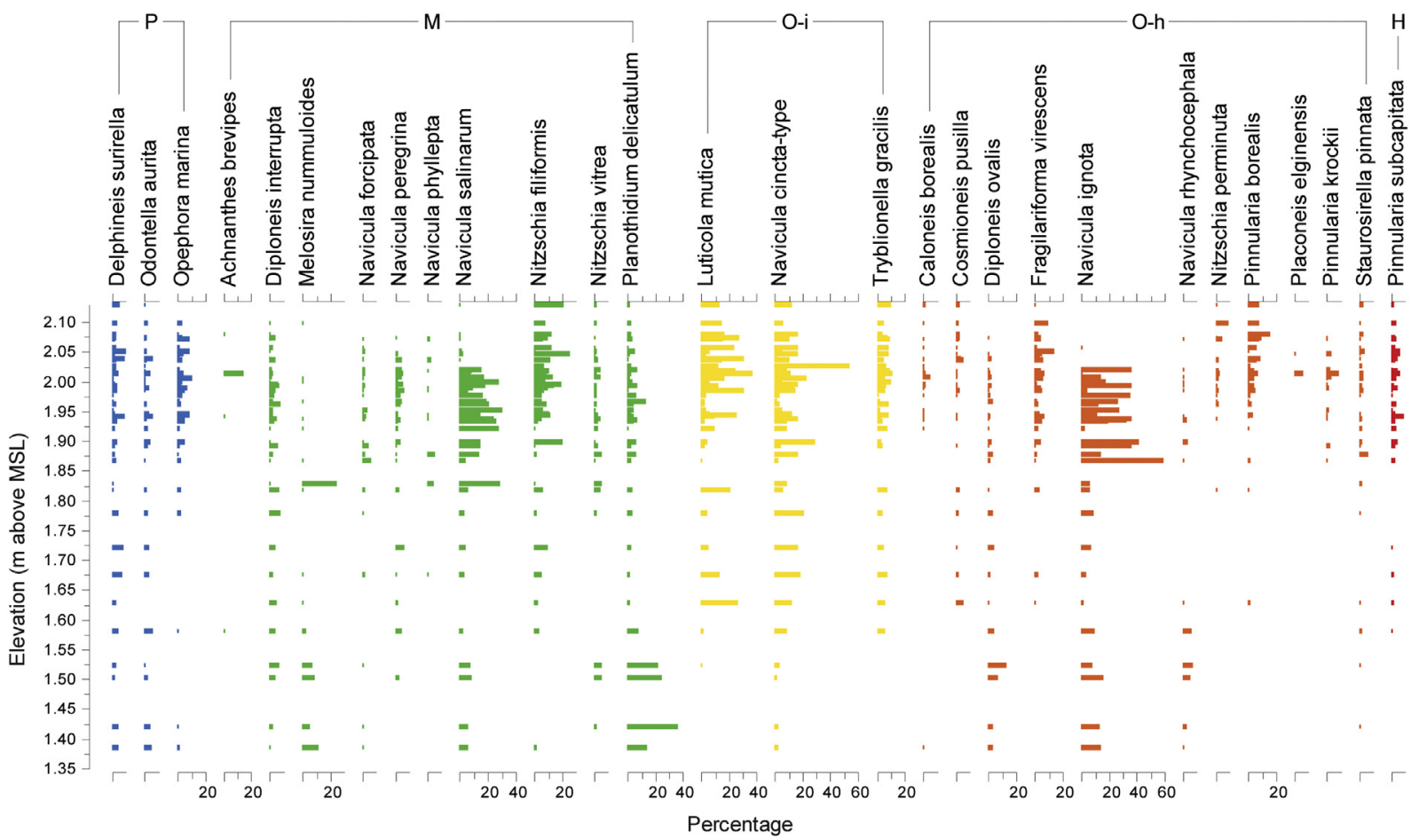

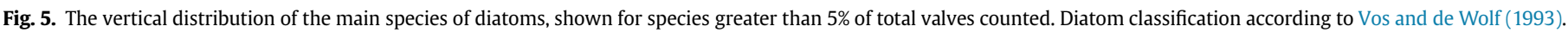

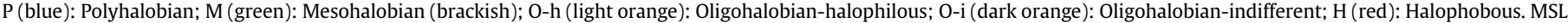
- mean sea level. (For interpretation of the references to colour in this figure legend, the reader is referred to the web version of this article.)

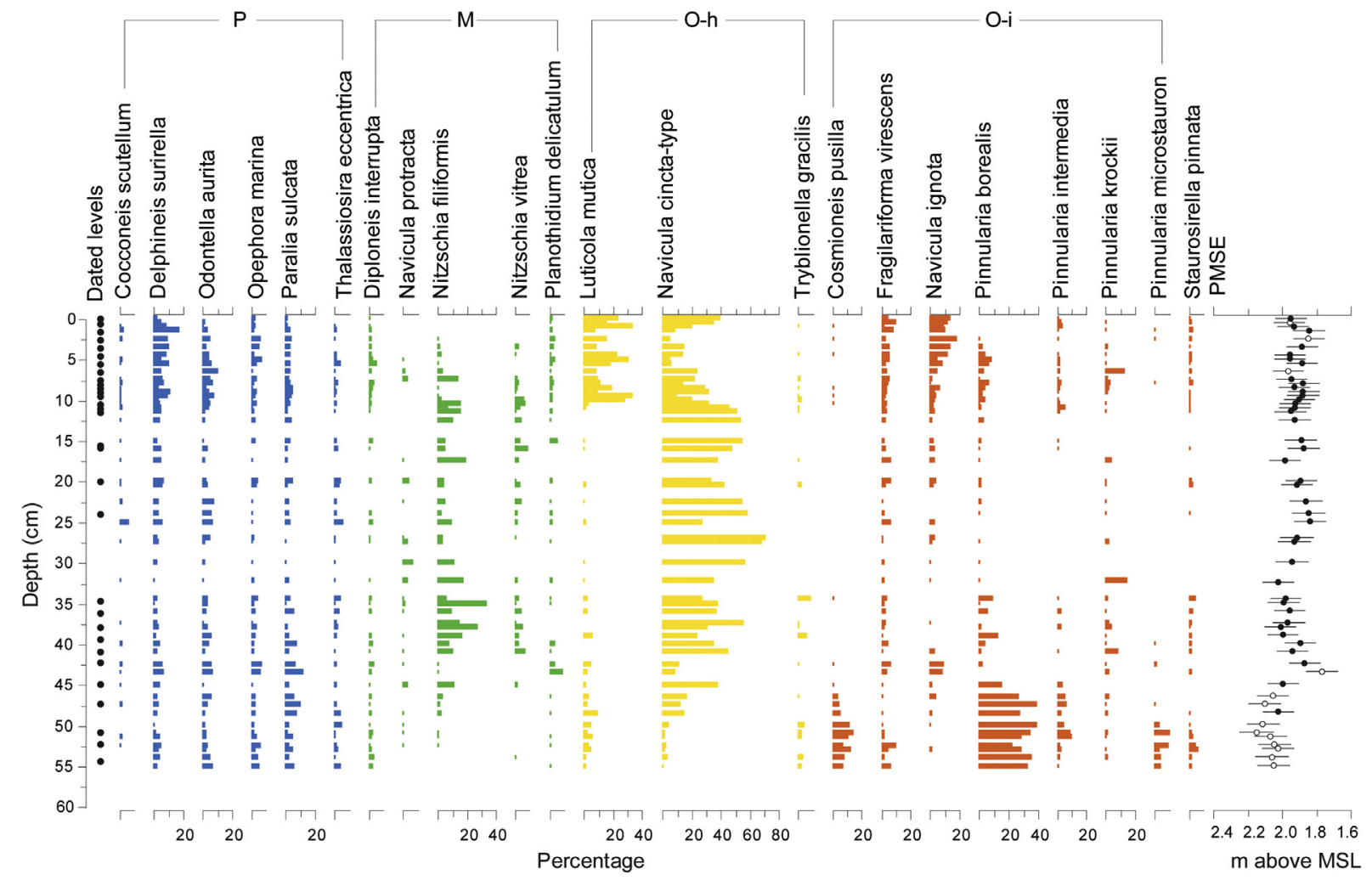

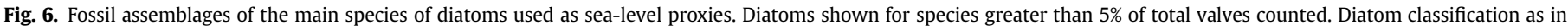

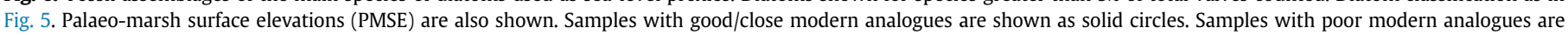
shown as open circles. 

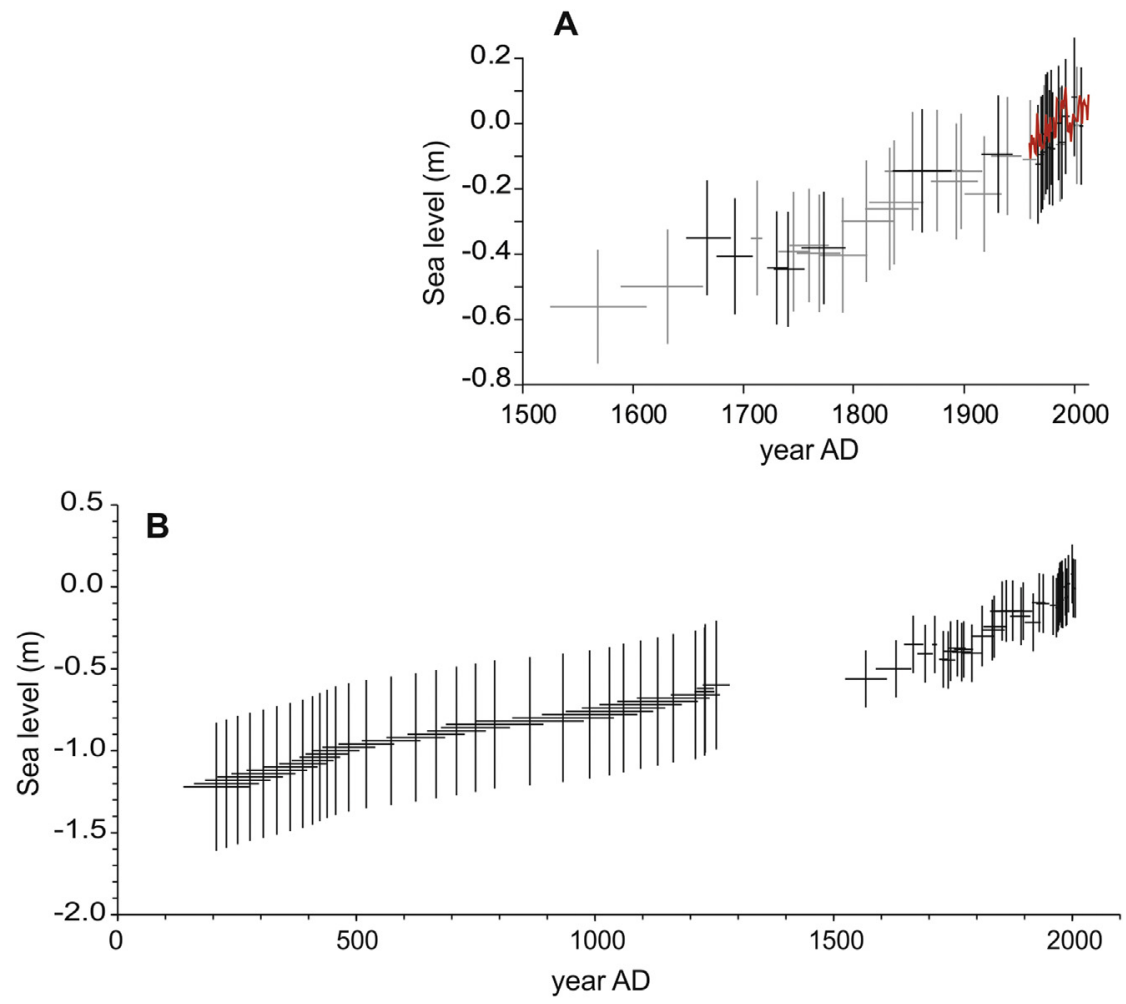

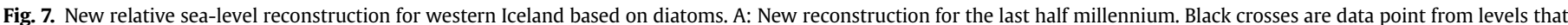

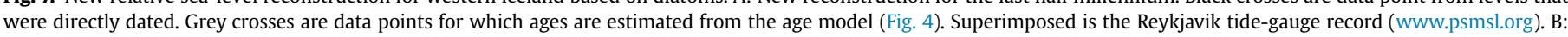

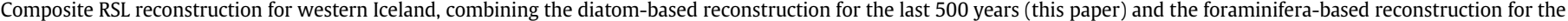
older part of the record (Gehrels et al., 2006).

Atlantic Oscillation (NAO) (e.g. Hurrell and Van Loon, 1997; Jones et al., 1997; Luterbacher et al., 1999, 2002; Cornes et al., 2013). We therefore first explore the relationship between the NAO and sea level in instrumental records, and then test the hypothesis that the periods of rapid sea-level rise in our Icelandic salt-marsh proxy record are synchronous with reconstructed changes in NAO.

The influence of the NAO on sea level has been established in different areas such as the North Sea area (Wakelin et al., 2003) and the Baltic (Andersson, 2002). The NAO, which is defined as the pressure difference between the Azores High and the Icelandic Low, can affect Icelandic sea level through air pressure changes and wind stress. Air pressure will influence sea level in its vicinity due to the inverted barometer effect which is $\sim 1 \mathrm{~cm} / \mathrm{mbar}$ (Ponte, 1992; Wunsch and Stammer, 1997); as air pressure rises (falls) so sea level falls (rises). The annual average pressure recorded by the Stykkishólmur weather station $(\sim 40 \mathrm{~km}$ from our field site; see Fig. 1) has varied by 12 mbar over the observational period (AD 1949-2012), which would translate into sea-level fluctuations of $\sim 12 \mathrm{~cm}$. The NAO, however, is mainly a winter phenomenon, and intra-annual variations in average winter (DJF) air pressure are considerably larger at 26 mbar. Additionally, the Icelandic Low dominates the wind patterns in the vicinity of our field site, and this pressure system is also known to influence sea level (e.g. Hong et al., 2000; Kolker and Hameed, 2007; Douglas, 2008).

To evaluate the possible effect of NAO on west Icelandic sea level, we compare (Fig. 8A-D) annual mean relative monthly sea level (RMSL) records from Reykjavik, with time-series of air pressure, wind speed, and wind direction, averaged across a box encompassing our study area (see Fig. 9), and the NAO index (http://www.cru.uea.ac.uk/ timo/datapages/naoi.htm). The timeseries of air pressure, wind speed and wind direction were derived from MSL pressure and $10 \mathrm{~m}$ wind fields, obtained from the 20th century global reanalysis dataset (Compo et al., 2011). These meteorological fields are available at a resolution of a data point every $6 \mathrm{~h}$ from 1871 to 2011 and have a horizontal resolution of $2^{\circ}$. Data were downloaded from the reanalysis web page (http://www. esrl.noaa.gov/psd/data/20thC_Rean/). We generated both annual averages and winter (DJF) averages (Fig. 8A-D). To reduce the considerable year-to-year variability we applied a 9-year running average (Fig. $8 \mathrm{E}-\mathrm{H}$ ) to the derived time-series (which is similar to the resolution of our proxy sea-level record). As expected, there is a negative correlation between (9-year smoothed) air pressure and MSL (annual: $r^{2}=0.08$; winter: $r^{2}=0.27$ ), which is explained by the inverted barometer effect. There is a positive correlation between MSL (9-year smoothed) and wind direction (annual: $r^{2}=0.01$; winter: $r^{2}=0.26$ ). There is a stronger (positive) correlation between MSL (9-year smoothed) and the NAO (annual: $r^{2}=0.27$; winter: $r^{2}=0.53$ ); and wind speed (annual: $r^{2}=0.54$; winter: $r^{2}=0.41$ ).

To further compare the atmospheric circulation near Iceland with the Reykjavik tide-gauge record, we detrend the tide-gauge record (using a linear trend fitted to the complete MSL timeseries) to remove lower-frequency variability such as that associated with changes in ocean volume. We subdivide the tide-gauge data into years in which MSL was $>+1 \mathrm{sd}, 0<+1 \mathrm{sd}, 0>-1 \mathrm{sd}$, and $<-1 \mathrm{sd}$, and calculate the average atmospheric patterns, over the period AD 1871-2011, for these categories (Fig. 9).

As noted above; the Icelandic Low, a persistent centre of low atmospheric pressure off the west coast of Iceland, tends to be deeper when sea levels at Reykjavik are higher. The dominant wind pattern involves strong winds from both the north and the south, resulting in a weak (though still significant) correlation of wind 

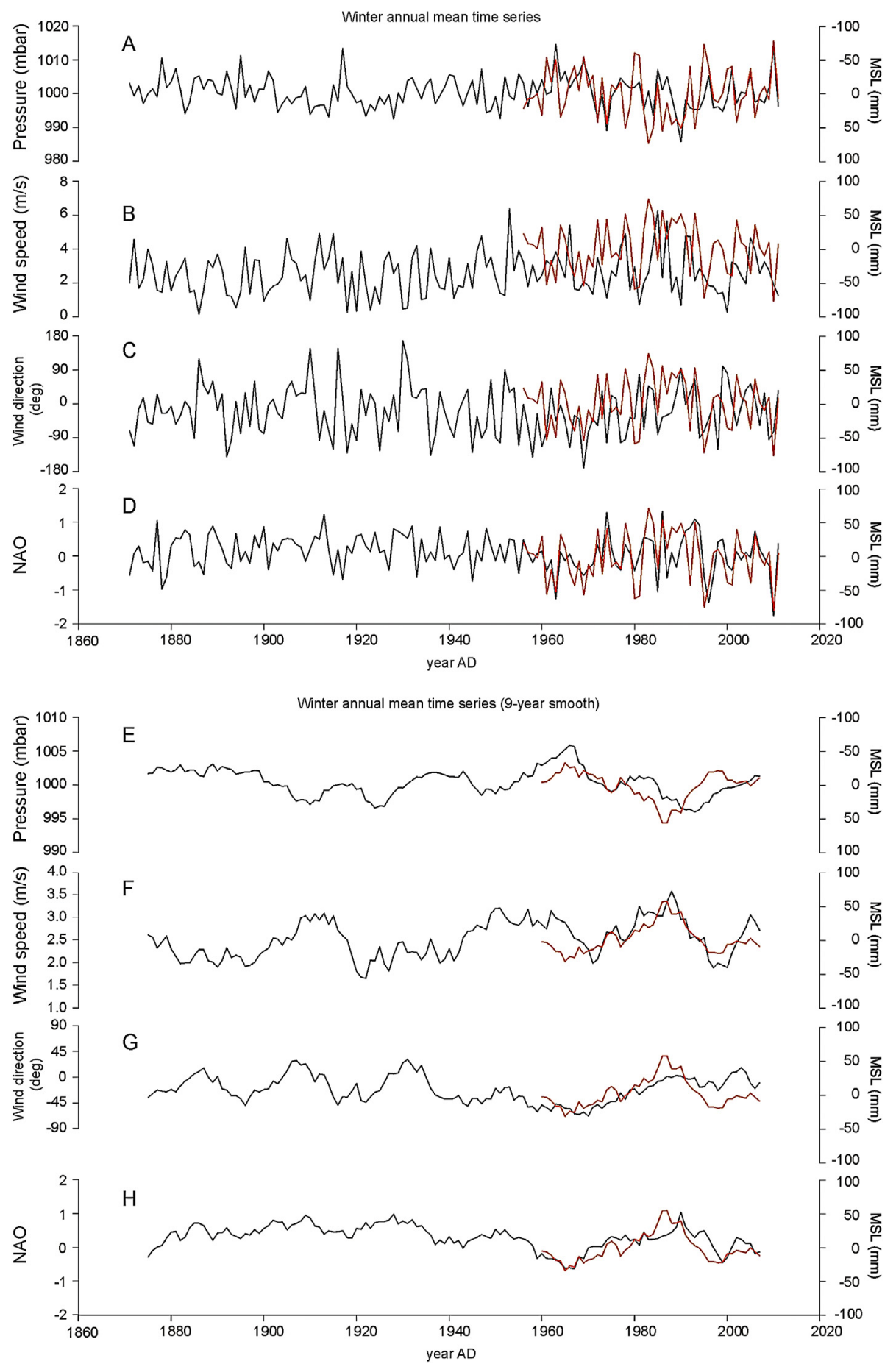

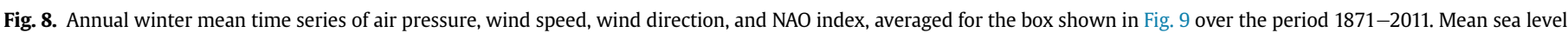

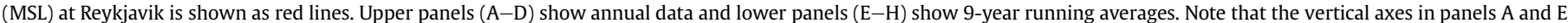
are reversed compared to the other panels. (For interpretation of the references to colour in this figure legend, the reader is referred to the web version of this article.)

direction with MSL, and a strong correlation with wind strength. The combined wind domains generate set-up on the western Icelandic coast.

The instrumental data reveal a strong correlation of NAO-related factors with instrumental measurements of sea level. In order to evaluate a potential link between our $~ 500$ year sea-level record and WNAO we examined several proxy-based reconstructions of wNAO (Glueck and Stockton, 2001; Luterbacher et al., 2002; Cook et al., 2002; Trouet et al., 2009). The Glueck and Stockton (2001) record is based on data from GISP, and dendrochronological data from Finland to represent the northern pole of the NAO, and many tree ring and precipitation records from the southern pole. The records by Cook et al. (2002) and Luterbacher et al. (2002) are both based on data from a plethora of sites on both sides of the Atlantic. The Trouet et al. (2009) record is based on winter precipitation records from Scotland and February-to-June drought records from Morocco. There are many reasons why proxy records of the NAO may differ (see Trouet et al., 2012 for a review), but we consider the 
(a) De-trended MSL

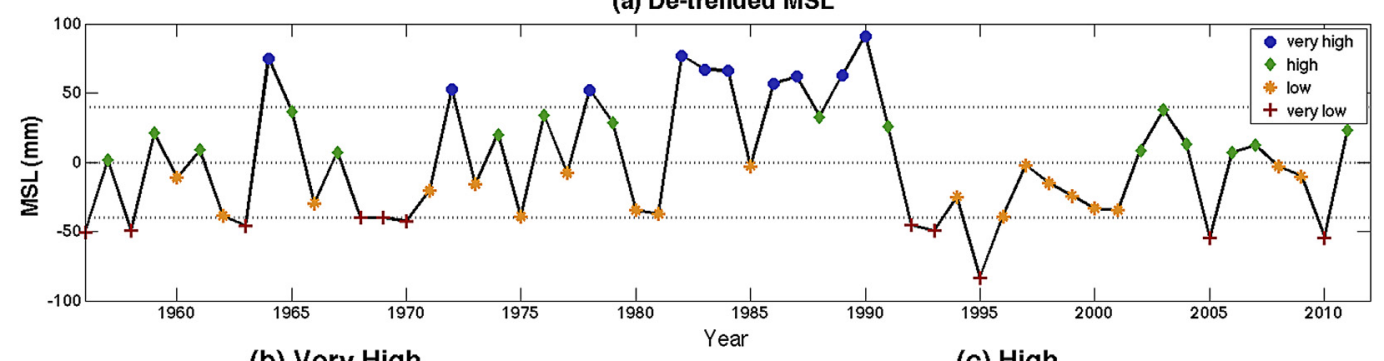

(b) Very High

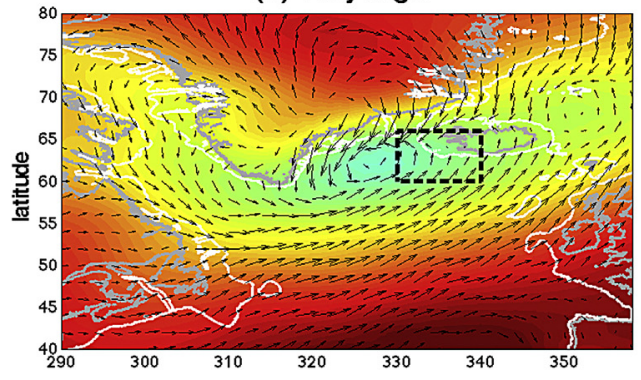

(d) Low

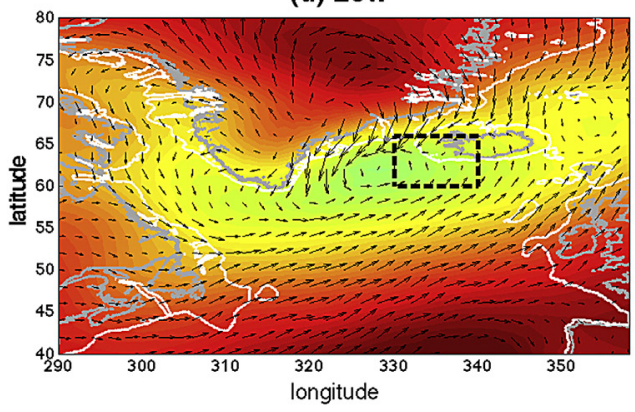

(c) High

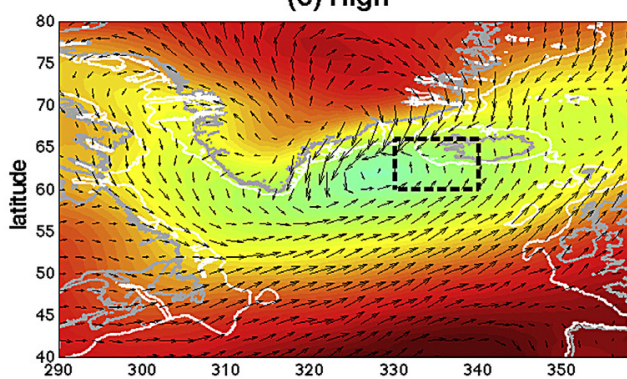

(e) Very Low

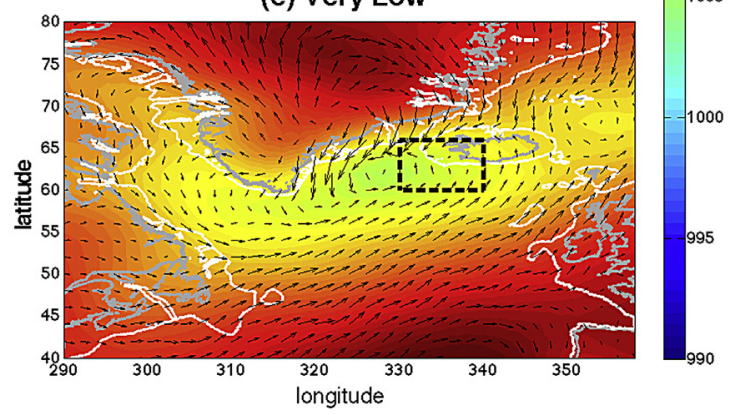

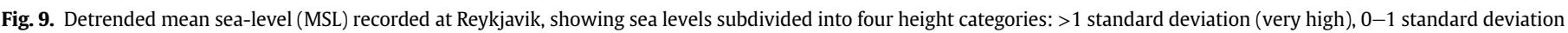

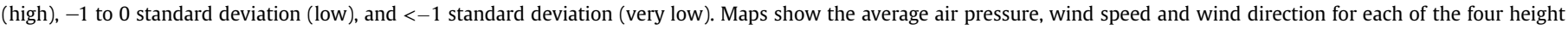
categories. The box shows the area used to calculate parameters shown in Fig. 8.

Trouet et al. (2009) reconstruction to be most suitable for comparing with the Iceland sea-level record due to its northwestern European northern pole, and the position of Scotland in the dominant wind patterns over the North Atlantic (Fig. 9).

In Fig. 10 we calculate from our sea-level reconstruction (Fig. 10A) rates of sea-level change (Fig. 10B) and identify three periods of rapid sea-level rise. We arbitrarily define 'rapid' as exceeding the average global sea-level rise during the 20th century (1.7 mm/yr, Church and White (2006)). The three periods are: AD 1620-1650, when sea-level rise peaked at $\sim 2 \mathrm{~mm} / \mathrm{yr}$, and AD 1780-1850 and AD 1950-2000, when maximum sea-level rise was $\sim 3 \mathrm{~mm} / \mathrm{yr}$ (These figures are based on the most probable interpretation of the data - see Section 3.4.). A comparison with the Trouet et al. (2009) wNAO record (Fig. 10C) shows that the three periods in which the rate of sea-level rise is highest are, within age error, synchronous with strong shifts toward a more positive wNAO. These shifts are by far the largest within the considered time period. Maximum rates of sea-level rise were achieved towards the end of the NAO shifts. The most recent period of rapid sea-level rise (late 20th century) also corresponds with strong shifts towards more positive wNAO in the records by Glueck and Stockton (2001), Cook et al. (2002), and Luterbacher et al. (2002) (Supplementary Fig. 1). Around AD 1800 Luterbacher et al. (2002) also record a marked increase in NAO index (Supplementary Fig. 1). The earliest period of rapid sea-level rise does not seem to have a corresponding signal in NAO records other than the one by
Trouet et al. (2009), but others have also found an increased correlation between Atlantic sea level and NAO in more recent centuries (e.g. Andersson, 2002).

From resampling the Trouet et al. (2009) NAO record at the same resolution as a detrended version of our RSL record (Supplementary Fig. 1B), which removes longer wavelength components of sea level, we calculate a coefficient of $0.3(p=0.05)$ for the correlation between RSL at Viðarhólmi and the NAO (Fig. 11). This suggests a significant influence of NAO on our $~ 500$-year sea level reconstruction, which is the longest record to date on which this is demonstrated.

Our sea-level record shows variability not detected in the record from North Carolina (Kemp et al., 2011) (Supplementary Fig. 1G). This is to be expected given the regionally specific forcing mechanisms of North Atlantic sea levels (Long et al., 2014). For example, along the Atlantic seaboard of the southeast USA sea levels may be influenced by the strength and position of the Gulf Stream (Ezer et al., 2013; Kopp, 2013) and easterly winds are dominant. Reconstructions of North Atlantic overturning circulation strength (e.g. Wanamaker et al., 2012) display little correspondence with our sea-level record.

\subsection{West Icelandic sea level and other driving mechanisms}

To evaluate the potential of other driving mechanisms we also consider ocean mass changes, GIA, and steric sea-level rise as 


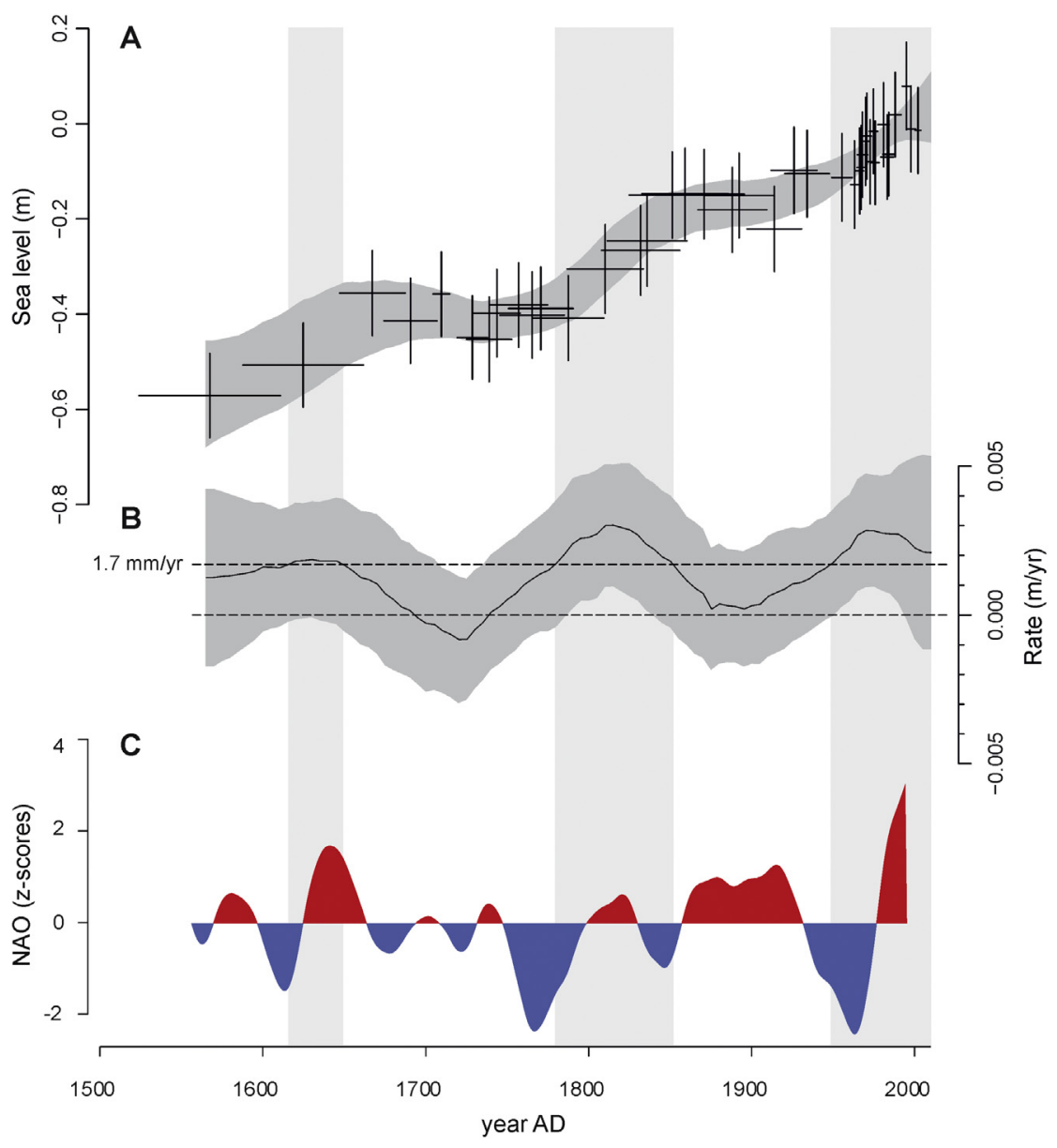

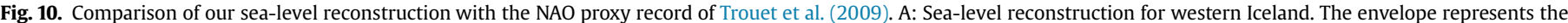

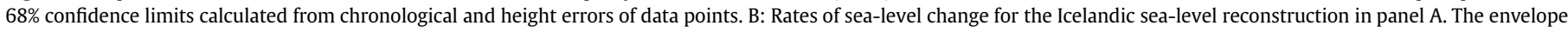

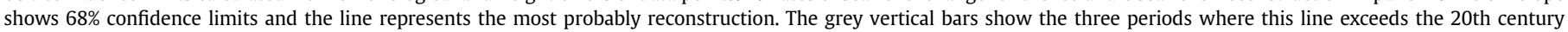
average of $1.7 \mathrm{~mm} / \mathrm{yr}$ (Church and White, 2006). C: The reconstructed NAO index of Trouet et al. (2009).

potential drivers of our Icelandic RSL record. Reductions in ice volume of the Greenland and Antarctic ice sheets and mountain glaciers produce a non-uniform sea-level response, with the largest sea-level rise observed in far-field locations (Mitrovica et al., 2001).

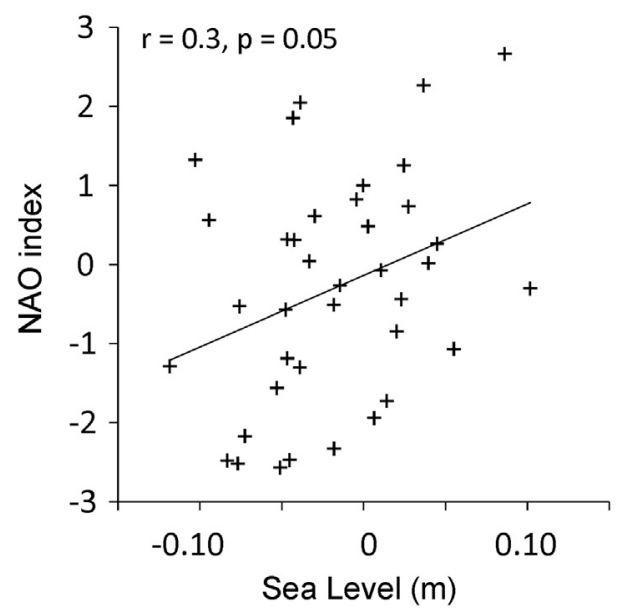

Fig. 11. Scatter plot showing the correlation between the detrended sea-level proxy data from western Iceland (see Supplementary Fig. 1B) and the reconstructed NAO index (Trouet et al., 2009).
Iceland is located too close to Greenland to be sensitive to any potential mass changes of the Greenland Ice Sheet. On the other hand, Iceland is in a far-field location with respect to Antarctica, but the lack of correlation with other North Atlantic sea-level records largely rules out any Antarctic melt signal as a cause of the sea-level variations we reconstructed. Although we cannot completely dismiss contributions from mountain glaciers, the absence of coherent signals in other sea-level proxy records indicates they would have been small or non-existent.

Our field site is quite far from the major ice fields in Iceland and the magnitude of vertical land motion due to changes in ice mass is estimated to be have been small in recent times (Árnadóttir et al., 2009) but may have varied in the past. We therefore examined GIA by comparing the timing of the periods of rapid sea-level rise with known changes in local ice load history in Iceland. Regional data exist from AD 1700 onwards (Supplementary Fig. 1H), whereas in the period $A D$ 1400-1700 ice volume changes are largely unconstrained (Kirkbride and Dugmore, 2008). The ice body most likely to produce crustal loading (and hence RSL rise) in the Viðarhólmi region is Langjökull, but data from other regional ice caps and glaciers are reported in Supplementary Fig. $1 \mathrm{H}$ for completeness. Of the two major glacial advances reported by Flowers et al. (2007), one coincides with rising and the other with falling sea level in our reconstruction, showing no coherent response of Viðarhólmi sea level to Langjökull mass changes. We therefore reject this as a cause of our reconstructed sea-level 
variability. Additionally, there is no obvious correlation between our sea-level variability and changes in more distant Icelandic ice masses (Supplementary Fig. 1H), and thus no suggestion these provided the forcing mechanism for this variability.

With regard to thermosteric sea-level rise we hypothesise that reconstructions of sea-surface temperature (SST) and sea-floor temperature (SFT) can be used as a proxy for steric sea level. We compare our record with two SST records and a SFT from marine core MD99-2275 (Supplementary Fig. 1I, J), taken from the North Icelandic Shelf (Knudsen et al., 2004; Ran et al., 2011; Sicre et al., 2011). Our coastal site and this core site are both dominated by Icelandic Coastal Water (Stefánsson and Ólafsson, 1991). There is no correspondence between the periods of rapid sea-level change and high SST/SFT, suggesting thermosteric effects on Viðarhólmi sea level are not significant.

\section{Conclusions}

Only a small number of well-dated late Holocene sea-level reconstructions from the North Atlantic are presently available, and these exhibit patterns that reflect a combination of local and regional signals (e.g. Long et al., 2014). It is important therefore to increase the spatial coverage of well dated sequences and to enhance the resolution of the RSL reconstructions where possible.

This study has improved an existing RSL record from Viðarhólmi salt marsh in western Iceland (Gehrels et al., 2006) by adding age control and by developing new quantitative sea-level reconstructions based on diatoms. Its main conclusions are as follows:

1) As shown in many other coastal locations, diatoms perform well as a sea-level proxy, due to their high species diversity, strong elevation control and frequent species turnover.

2) The careful application of the optimal microfossil group (here, diatoms) can improve RSL reconstructions, but such work must proceed in tandem with the construction of precise age models. We developed a new age model for Viðarhólmi using a combination of AMS ${ }^{14} \mathrm{C}$ dates, ${ }^{137} \mathrm{Cs}$, geochemical and magnetic markers, as well as a tephra horizons.

3) We developed new diatom-based RSL reconstructions, using the modern analogue technique (MAT), to identify and remove samples that have poor contemporary equivalents. After screening our reconstruction shows a $\sim 0.6 \mathrm{~m}$ overall (non-GIA corrected) RSL rise since AD 1570, and three episodes of rapid $\mathrm{RSL}$ when the rate of rise exceeded $1.7 \mathrm{~mm} / \mathrm{yr}$ : AD 1620-1650, AD 1780-1850 and AD 1950-2000.

4) We hypothesise that Icelandic sea-level variability is controlled by changes in wind patterns associated with shifts in NAO phase based on the strong correlation between a reconstructed NAO index (Trouet et al., 2009) and our detrended RSL record. This result is supported by a positive correlation of the Reykjavik tide-gauge record with regional air pressure and wind speed. NAO-related wind patterns generate set-up on the west coast of Iceland thereby raising local sea level. Taking into account the potential impact of NAO on Icelandic sea level will enhance future predictions of sea-level changes in this region.

5) The fluctuating nature of the Icelandic RSL record contrasts with other records from the North Atlantic and highlights the importance of regionally specific driving mechanisms over centennial timescales.

\section{Acknowledgements}

This research was funded by the Natural Environment Research Council (grant no. NE/G003440/1). Radiocarbon dating was performed with help from the Natural Environment Research Council Radiocarbon Committee (allocations 1490.0810 and 1604.0112). Tephrochronology was performed with support from the Tephrochronology Analytical Unit (allocation TAU71/1011). We thank James Scourse and an anonymous reviewer for their constructive comments. We thank Chris Hayward and Donald Herd for help with the tephra analyses, and Gudrun Larsen for advice and for a reference sample of Katla 1721 ash. We thank the Icelandic Met Office for supplying climate data. We thank Peter Schmidt and Björn Lund for advice on GIA and William Marshall for assistance in the field. The paper is a contribution to IGCP project 588 ("Preparing for Coastal Change”) and to PALSEA2 (an INQUA International Focus Group and a PAGES working group).

\section{Appendix A. Supplementary data}

Supplementary data related to this article can be found at http:// dx.doi.org/10.1016/j.quascirev.2014.11.005.

\section{References}

Andersson, H.C., 2002. Influence of long-term regional and large-scale atmospheric circulation on the Baltic sea level. Tellus A 54, 76-88.

Angelier, J., Slunga, R., Bergerat, F., Stefansson, R., Homberg, C., 2004. Perturbation of stress and oceanic rift extension across transform faults shown by earthquake focal mechanisms in Iceland. Earth Planet. Sci. Lett. 219, 271-284.

Angell, J.K., Korshover, T., 1974. Quasi-biennial and long-term fluctuations in the centers of action. Mon. Weather Rev. 102, 669-678.

Árnadóttir, T., Lund, B., Jiang, W., Geirsson, H., Björnsson, H., Einarsson, P., Sigurdsson, T., 2009. Glacial rebound and plate spreading: results from the first countrywide GPS observations in Iceland. Geophys. J. Int. 177, 691-716.

Barlow, N.L.M., Shennan, I., Long, A.J., 2012. Relative sea-level response to Little Ice Age ice mass change in south central Alaska: reconciling model predictions and geological evidence. Earth Planet. Sci. Lett. 315-316, 62-75.

Barlow, N.L.M., Shennan, I., Long, A.J., Gehrels, W.R., Saher, M.H., Woodroffe, S.A., Hillier, C., 2013. Salt marshes as late Holocene tide gauges. Glob. Planet. Change 106, 90-110.

Barlow, N.L.M., Long, A.J., Saher, M.H., Gehrels, W.R., Garnett, M.H., Scaife, R.G., 2014. Salt-marsh reconstructions of relative sea-level change in the North Atlantic during the last 2000 years. Quat. Sci. Rev. 99, 1-16.

Birks, H.J.B., Line, J.M., Juggins, S., Stevenson, A.C., Braak, C.J.F.T., 1990. Diatoms and pH reconstruction. Philos. Trans. R. Soc. Lond. B Biol. Sci. 327, 263-278.

Blaauw, M., Christen, J.A., 2011. Flexible paleoclimate age-depth models using an autoregressive gamma process. Bayesian Anal. 6, 457-474.

Brain, M.J., Long, A.J., Woodroffe, S.A., Petley, D.N., Milledge, D.G., Parnell, A.C., 2012. Modelling the effects of sediment compaction on salt marsh reconstructions of recent sea-level rise. Earth. Planet. Sci. Lett. 345-348, 180-193.

Bronk Ramsey, C., Gigham, T., Leach, P., 2004. Towards high-precision AMS; progress and limitations. Radiocarbon 46, 17-24.

Carleton, A.M., 1988. Meridional transport of Eddy sensible heat in Winters marked by extremes of the North Atlantic Oscillation, 1948/49-1979/80. J. Clim. 1, $212-223$.

Charman, D.J., Gehrels, W.R., Manning, C., Sharma, C., 2010. Reconstruction of recent sea-level change using testate amoebae. Quat. Res. 73, 208-219.

Church, J.A., White, N.J., 2006. A 20th century acceleration in global sea-level rise Geophys. Res. Lett. 33, L01602. http://dx.doi.org/10.1029/2005GL024826.

Compo, G.P., Whitaker, J.S., Sardeshmukh, P.D., Matsui, N., Allan, R.J., Yin, X., Gleason, B.E., Vose, R.S., Rutledge, G., Bessemoulin, P., Brönnimann, S., Brunet, M., Crouthamel, R.I., Grant, A.N., Groisman, P.Y., Jones, P.D., Kruk, M.C., Kruger, A.C., Marshall, G.J., Maugeri, M., Mok, H.Y., Nordli, Ø., Ross, T.F., Trigo, R.M., Wang, X.L., Woodruff, S.D., Worley, S.J., 2011. The twentieth century reanalysis project. Quart. J. R. Meteorol. Soc. 137, 1-28.

Cook, E.R., D'Arrigo, R.D., Mann, M.E., 2002. A well-verified, multiproxy reconstruction of the Winter North Atlantic Oscillation Index since A.D. 1400. J. Clim. 15, 1754-1764.

Cornes, R.C., Jones, P.D., Briffa, K.R., Osborn, T.J., 2013. Estimates of the North Atlantic Oscillation back to 1692 using a Paris-London westerly index. Int. J. Clim. 33, $228-248$.

Davies, S.M., Elmquist, M., Bergman, J., Wohlfarth, B., Hammarlund, D., 2007. Cryptotephra sedimentation processes within two lacustrine sequences from west central Sweden. Holocene 17, 319-330.

Douglas, B.C., 2008. Concerning evidence for fingerprints of glacial melting. J. Coast. Res. 24, 218-227.

Einarsson, M.A., 1984. Climate of Iceland. World Surv. Climatol. 15, 673-697.

Einarsson, E.H., Larsen, G., Pórarinsson, S., 1980. The Sólheimar tephra layer and the Katla eruption of 1357. Acta Nat. Isl. 28, 1-24. 
Ezer, T., Atkinson, L.P., Corlett, W.B., Blanco, J.L., 2013. Gulf Stream's induced sea level rise and variability along the U.S. mid-Atlantic coast. J. Geophys. Res. Oceans 118, 685-697.

Flowers, G.E., Björnsson, H., Geirsdóttir, Á., Miller, G.H., Clarke, G.K.C., 2007. Glacier fluctuation and inferred climatology of Langjökull ice cap through the Little Ice Age. Quat. Sci. Rev. 26, 2337-2353.

Foged, N., 1974. Freshwater diatoms in Iceland. Bibl. Phycol. 15, 1-118.

Gehrels, W.R., 1999. Middle and Late Holocene sea-level changes in eastern Maine reconstructed from foraminiferal saltmarsh stratigraphy and AMS ${ }^{14} \mathrm{C}$ dates on basal peat. Quat. Res. 52, 350-359.

Gehrels, W.R., Woodworth, P.L., 2013. When did modern rates of sea-level rise start? Glob. Planet. Change 100, 263-277.

Gehrels, W.R., Roe, H.M., Charman, D.J., 2001. Foraminifera, testate amoebae and diatoms as sea-level indicators in UK saltmarshes: a quantitative multiproxy approach. J. Quat. Sci. 16, 201-220.

Gehrels, W.R., Kirby, J.R., Prokoph, A., Newnham, R.M., Achterberg, E.P., Evans, H. Black, S., Scott, D.B., 2005. Onset of recent rapid sea-level rise in the western Atlantic Ocean. Quat. Sci. Rev. 24, 2083-2100.

Gehrels, W.R., Milne, G.A., Kirby, J.R., Patterson, R.T., Belknap, D.F., 2004. Late Holocene sea-level changes and isostatic crustal movements in Atlantic Canada. Quat. Int. 120, 79-89.

Gehrels, W.R., Marshall, W.A., Gehrels, M.J., Larsen, G., Kirby, J.R., Eiriksson, J. Heinemeier, J., Shimmield, T., 2006. Rapid sea-level rise in the North Atlantic Ocean since the first half of the nineteenth century. Holocene 16 949-965.

Glueck, M.F., Stockton, C.W., 2001. Reconstruction of the North Atlantic Oscillation, 1429-1983. Int. J. Climatol. 21, 1453-1465.

Haflidason, H., Larsen, G., Ólafsson, G., 1992. The recent sedimentation history of Thingvallavatn, Iceland. Oikos 64, 80-95.

Haflidason, H., Eiriksson, J., Kreveld, S.V., 2000. The tephrochronology of Iceland and the North Atlantic region during the Middle and Late Quaternary: a review. J. Quat. Sci. 15, 3-22.

Haigh, I., Nicholls, R., Wells, N., 2010. Assessing changes in extreme sea levels: application to the English Channel, 1900-2006. Cont. Shelf Res. 30, 1042-1055.

Hartley, B., Barber, H.G., Carter, J.R., 1996. An Atlas of British Diatoms. Biopress Bristol, $601 \mathrm{pp}$

Hayward, C., 2012. High spatial resolution electron probe microanalysis of tephras and melt inclusions without beam-induced chemical modification. Holocene $22,119-125$.

Hemphill-Haley, E., 1993. Taxonomy of Recent and Fossil (Holocene) Diatoms (Bacillariophyta) from Northern Willapa Bay, Washington. U.S. Department of the Interior, US Geological Survey, 151 pp.

Hong, B.G., Sturges, W., Clarke, A.J., 2000. Sea level on the U.S. East Coast: decadal variability caused by open ocean wind-curl forcing. J. Phys. Ocean. 30, 2088-2098.

Hurrell, J., Van Loon, H., 1997. Decadal variations in climate associated with the North Atlantic Oscillation. Clim. Change 36, 301-326.

Hurrell, J.W., Kushnir, Y., Ottersen, G., Visbeck, M., 2003. An overview of the North Atlantic oscillation. Geophys. Mon. Am. Geophys. Union 134, 1-36.

Hustedt, F., 1953. Die Systematik der Diatomeen in ihren Beziehungen zur Geologie und Okologie nebst einer Revision des Halobien-systems. Sven. Bot. Tidskr. 47, 509-519.

Ingólfsson, A., 1998. Sjávarfitjar. In: Ólafsson, J.S. (Ed.), Íslensk votlendiverndun og nýting. Háskólaútgáfan, pp. 57-68.

Jackson, S.T., Williams, J.W., 2004. Modern analogs in Quaternary paleoecology: here today, gone yesterday, gone tomorrow? Ann. Rev. Earth Planet. Sci. 32 495-537.

Jevrejeva, S., Grinsted, A., Moore, J.C., Holgate, S., 2006. Nonlinear trends and multiyear cycles in sea level records. J. Geophys. Res. 111, C09012. http:// dx.doi.org/10.1029/2005JC003229.

Jones, P.D., Jonsson, T., Wheeler, D., 1997. Extension to the North Atlantic oscillation using early instrumental pressure observations from Gibraltar and south-west Iceland. Int. J. Clim. 17, 1433-1450.

Juggins, S., 2003. C2 User Guide. Software for Ecological and Palaeoecologica Data Analysis and Visualisation. University of Newcastle, Newcastle upon Tyne, UK.

Kemp, A.C., Horton, B.P., Corbett, D.R., Culver, S.J., Edwards, R.J., van de Plassche, O, 2009. The relative utility of foraminifera and diatoms fo reconstructing late Holocene sea-level change in North Carolina, USA. Quat. Res. 71, 9-21.

Kemp, A.C., Horton, B.P., Donnelly, J.P., Mann, M.E., Vermeer, M., Rahmstorf, S., 2011 Climate related sea-level variations over the past two millennia. Proc. Nat. Acad. Sci. 108, 11017-11022.

Kemp, A.C., Horton, B.P., Vane, C.H., Bernhardt, C.E., Corbett, D.R., Engelhart, S.E. Anisfeld, S.C., Parnell, A.C., Cahill, N., 2013. Sea-level change during the last 2500 years in New Jersey, USA. Quat. Sci. Rev. 81, 90-104.

Kirkbride, M.P., Dugmore, A.J., 2008. Two millennia of glacier advances from southern Iceland dated by tephrochronology. Quat. Res. 70, 398-411.

Knudsen, K.L., Eiríksson, J., Jansen, E., Jiang, H., Rytter, F., Gudmundsdóttir, R.E 2004. Palaeoceanographic changes off North Iceland through the last 1200 years: foraminifera, stable isotopes, diatoms and ice rafted debris. Quat. Sci. Rev. 23, 2231-2246.

Kolker, A.S., Hameed, S., 2007. Meteorologically driven trends in sea level rise. Geophys. Res. Lett. 34, L23616.
Kopp, R.E., 2013. Does the mid-Atlantic United States sea level acceleration hot spot reflect ocean dynamic variability? Geophys. Res. Lett. 40, 3981-3985.

Larsen, G., 2000. Holocene eruptions within the Katla volcanic system, south Iceland: characteristics and environmental impact. Jökull 49, 1-28.

Long, A.J., Barlow, N.L.M., Gehrels, W.R., Saher, M.H., Woodworth, P.L., Scaife, R.G., Brain, M.J., Cahill, N., 2014. Contrasting records of sea-level change in the eastern and western North Atlantic during the last 300 years. Earth Planet. Sci. Lett. 388, 110-122.

Luterbacher, J., Schmutz, C., Gyalistras, D., Xoplaki, E., Wanner, H., 1999. Reconstruction of monthly NAO and EU indices back to AD 1675. Geophys. Res. Lett. 26, 2745-2748.

Luterbacher, J., Xoplaki, E., Dietrich, D., Jones, P.D., Davies, T.D., Portis, D., GonzalezRouco, J.F., von Storch, H., Gyalistras, D., Casty, C., Wanner, H., 2002. Extending North Atlantic oscillation reconstructions back to 1500. Atmos. Sci. Lett. 2, $114-124$.

Miller, L., Douglas, B.C., 2007. Gyre-scale atmospheric pressure variations and their relation to 19th and 20th century sea level rise. Geophys. Res. Lett. 34, L16602. http://dx.doi.org/10.1029/2007GL030862.

Milne, G.A., Gehrels, W.R., Hughes, C.W., Tamisiea, M.E., 2009. Identifying the causes of sea-level change. Nat. Geosci. 2, 471-478.

Mitrovica, J.X., Tamisiea, M.E., Davis, J.L., Milne, G.A., 2001. Recent mass balance of polar ice sheets inferred from patterns of global sea-level change. Nature 409, 1026-1029.

Óladóttir, B., Sigmarsson, O., Larsen, G., Thordarson, T., 2008. Katla volcano, Iceland: magma composition, dynamics and eruption frequency as recorded by Holocene tephra layers. Bull. Volcanol. 70, 475-493.

Overpeck, J.T., Webb III, T., Prentice, I.C., 1985. Quantitative interpretation of fossil pollen spectra: dissimilarity coefficients and the method of modern analogs. Quat. Res. 23, 87-108.

Palmer, A.J., Abbott, W.H., 1986. Diatoms as indicators of sea level change. In: Van de Plassche, O. (Ed.), Sea Level Research: a Manual for the Collection and Evaluation of Data. Geobooks, Norwich, pp. 457-488.

Patterson, R.T., Hutchinson, I., Guilbault, J.P., Clague, J.J., 2000. A comparison of the vertical zonation of diatom, foraminifera, and macrophyte assemblages in a coastal marsh; implications for greater paleo-sea level resolution. Micropaleontology 46, 229-244.

Ponte, R.M., 1992. The sea level response of a stratified ocean to barometric pressure forcing. J. Phys. Oceanogr. 22, 109-113.

Ran, L., Jian, g H., Knudsen, K.L., Eiríksson, J., 2011. Diatom-based reconstruction of palaeoceanographic changes on the North Icelandic shelf during the last millennium. Palaeogeogr. Palaeoclim. Palaeoecol, 302, 109-119.

Serreze, M.C., Carse, F., Barry, R.G., Rogers, J.C., 1997. Icelandic Low cyclone activity: climatological features, linkages with the NAO, and relationships with recent changes in the Northern Hemisphere circulation. J. Clim. 10, 453-464.

Sicre, M.A., Hall, I.R., Mignot, J., Khodri, M., Ezat, U., Truong, M.X., Eiríksson, J., Knudsen, K.L., 2011. Sea surface temperature variability in the subpolar Atlantic over the last two millennia. Paleoceanography 26, PA4218. http://dx.doi.org/ 10.1029/2011PA002169.

Sigurgeirsson, M.A., 1992. Gjoskumyndanir a Reykjanesi (MSc thesis). University of Iceland, $113 \mathrm{pp}$.

Simpson, G.L., 2007. Analogue methods in palaeoecology: using the analogue package. J. Stat. Softw. 22, 1-29.

Stefánsson, U., Ólafsson, J., 1991. Nutrients and fertility of Icelandic waters. Rit Fiskid. 7, 1-56.

Ter Braak, C.J.F., Juggins, S., 1993. Weighted averaging partial least squares regression (WA-PLS): an improved method for reconstructing environmental variables from species assemblages. Hydrobiologia 269-270, 485-502.

Ter Braak, C.J.F., Prentice, I.C., 1988. A theory of gradient analysis. Adv. Ecol. Res. 34.

Ter Braak, C.J.F., Smilauer, P., 2002. CANOCO Reference Manual and CanoDraw for Windows User's Guide: Software for Canonical Community Ordination (Version 4.5).

Trouet, V. Esper, J., Graham, N.E. Baker, A Scourse J.D. Frank, D.C. 2009. Persistent positive North Atlantic Oscillation mode dominated the medieval climate anomaly. Science 324, 78-80.

Trouet, V., Scourse, J.D., Raible, C.C., 2012. North Atlantic storminess and Atlantic Meridional Overturning Circulation during the last Millennium: reconciling contradictory proxy records of NAO variability. Glob. Planet. Change 84-85, 48-55.

Tsimplis, M.N., Woolf, D.K., Osborn, T.J., Wakelin, S., Wolf, J., Flather, R., Shaw, A.G.P., Woodworth, P., Challenor, P., Blackman, D., Pert, F., Yan, Z. Jevrejeva, S., 2005. Towards a vulnerability assessment of the UK and northern European coasts: the role of regional climate variability. Philos. Trans. R. Soc. A 363, 1329-1358.

Tsimplis, M.N., Shaw, A.G.P., Flather, R.A., Woolf, D.K., 2006. The influence of the North Atlantic Oscillation on the sea-level around the northern European coasts reconsidered: the thermosteric effects. Philos. Trans. R. Soc. A 364, 845-856.

Van de Plassche, O., 2000. North Atlantic climate-ocean variations and sea level in Long Island Sound, Connecticut, since 500 cal yr A.D. Quat. Res. 53, 89-97.

Van der Werff, A., Huls, H., 1957-1974. Diatomeeënflora van Nederland. Reprinted 1976. Otto Koeltz Science Publishers, Koenigstein. West Germany.

Vos, P.C., de Wolf, H., 1993. Diatoms as a tool for reconstructing sedimentary environments in coastal wetlands; methodological aspects. Hydrobiologia 269, 285-296.

Wakelin, S.L., Woodworth, P.L., Flather, R.A., Williams, J.A., 2003. Sea-level dependence on the NAO over the NW European Continental Shelf. Geophys. Res. Lett. 30, 1403. 
Wanamaker, A.D.J., Butler, P.G., Scourse, J.D., Heinemeier, J., Eiríksson, J., Knudsen, K.L., Richardson, C.A., 2012. Surface changes in the North Atlantic meridional overturning circulation during the last millennium. Nat. Comm. 3 , 899.

Ward, P.L., 1971. New interpretation of the geology of Iceland. Geol. Soc. Am. Bull. 82, 2991-3012.

Watcham, E.P., Shennan, I., Barlow, N.L.M., 2013. Scale considerations in using diatoms as indicators of sea-level change: lessons from Alaska. J. Quat. Sci. 28, 165-179.
Woodworth, P.L., Flather, R.A., Williams, J.A., Wakelin, S.L., Jevrejeva, S., 2007. The dependence of UK extreme sea levels and storm surges on the North Atlantic Oscillation. Cont. Shelf Res. 27, 935-946.

Woolf, D.K., Shaw, A.G., Tsimplis, M.N., 2003. The influence of the North Atlantic Oscillation on sea-level variability in the North Atlantic region. Glob. Atmos. Ocean Syst. 9, 145-167.

Wunsch, C., Stammer, D., 1997. Atmospheric loading and the oceanic "inverted barometer" effect. Rev. Geophys. 35, 79-107. 